\title{
Factors influencing the sodium content of meadow grass
}

\author{
CH. H. HENKENS \\ Institute for Soil Fertility, Groningen, Netherlands
}

\section{Summary and conclusions}

Cattle are not usually given minerals during the grazing period, and the use of salt lick and pickle ( $2 \frac{1}{2} \%$ solution of sodium chloride) is uncommon. Consequently, the cattle's sodium supply during this period depends on the sodium content of the grass. It is important to study the factors influencing the sodium content of the grass, so that a detailed investigation has been undertaken.

The factors influencing the sodium content of meadow grass have been divided into three groups, viz. soil fertility, fertilisers ( $\mathrm{K}, \mathrm{N}, \mathrm{Mg}$ and $\mathrm{Na}$ ) and botanical composition.

The following conclusions are drawn :

1. The sodium content of grass is largely determined by sodium content and $\mathrm{K}$-number of the soil.

2. At a given sodium content of the soil the sodium content of grass decreases with increasing $\mathrm{K}$-numbers of the soil. This decrease in the sodium content of grass is small at high $\mathrm{K}$ numbers $(>30)$.

3. The sodium content of grass increases with increasing sodium content of the soil. The influence of the sodium content of the soil is higher at a low soil-potassium status than at a high one.

4. Potash fertilisers reduce the sodium content of grass at a low soil-potassium status.

5. The soil-sodium content may be used as a basis for sodium-fertiliser recommendations, since with the present potassium-fertiliser policy in the Netherlands, the K-number has generally reached a level at which it has a virtually constant effect on the sodium content of grass.

6. The influence on the sodium content of grass, mentioned under 2 and 3 , can be expressed by means of the $\frac{15 \mathrm{~K} \text {-number }}{\mathrm{Na}_{2} \mathrm{O}+6}$ and $\frac{25 \mathrm{~K} \text {-number }}{\mathrm{Na}_{2} \mathrm{O}+14}$ ratios for sandy and clay soils respectively, the numerator at $\mathrm{K}$-numbers $>30$ being the same as that at $\mathrm{K}$-number $=30$. With increasing ratios the sodium content of grass decreases. The influence of a given amount of sodium in potash fertilisers on sodium content of grass is correlated to these ratios.

7. The influence of nitrogen fertilisers on the sodium content of grass is not clear.

8. The influence of magnesium fertilisation on the sodium content of grass is negligible.

9. The Chilean-nitrate sodium has the same effect as that in sodium chloride. Unlike the case of $\mathrm{NaCl}$, the calcium content of grass is decreased by Chilean nitrate. Both fertilisers slightly reduce the magnesium content of grass.

10. Herbs and clovers have a higher sodium content than grass. The sodium content of the plants belonging to each group is correlated to the calculated ratios in the soil as mentioned under 6 .

\section{Introduction}

It has long been known that animals require sodium. The sodium supply in winter time is usually sufficient as minerals are commonly given and mineral mixtures generally contain sodium chloride. During the grazing period, however, cattle usually have

Received for publication 4th June, 1964. 
no mineral supply, and the use of salt lick and pickle $(21 / 2 \%$ solution of $\mathrm{NaCl})$ is not widespread. The cattle's sodium supply during this period therefore depends on the sodium content of the grass.

It is therefore important to know in the first place how the sodium content of meadow grass is influenced by various factors, and to suggest ways of increasing sodium content where necessary.

The factors influencing the sodium content of meadow grass are : -

1. soil fertility,

2. manuring,

3. botanical composition of the grass.

Literature. Many investigations have shown that the sodium uptake of plants decreases with increasing potassium uptake. VAN ITALLIE (1938) concluded from pot experiments that the sodium content of Westerwolds ryegrass (Lolium multiflorum var. westerwoldicum) depends on the ratio of the amount of soluble and exchangeable sodium to potassium, calcium and magnasium in the soil, viz. $\frac{10 \mathrm{Na}}{0,1 \mathrm{Ca}+0,2 \mathrm{Mg}+2 \mathrm{~K}}$ (in m.eq.). OOSTENDORP (1962) concluded that the sodium content of grass depends on the $\mathrm{K}_{2} \mathrm{O}$ / $\mathrm{Na} 2 \mathrm{O}$-ratio (both soluble in $1 / 10 \mathrm{~N} \mathrm{HCl}$ ).

The sodium uptake has been frequently studied, especially with beets, and the part played by sodium as a substitute for potassium (VAN ITALLIE, 1937a) has been taken into account. A review of the literature on the influence of potassium on the sodium uptake of the plant has been given by HeIMANN and RATNER (1962). LeHR's experiments showed that high potash dressings in the form of $60 \%$ potash salt considerably reduce the sodium content of grass. But with moderate dressings of $20 \%$ sodiumcontaining potash salt, the sodium content appeared to increase.

VaN ITALLIE (1934) pointed out that the composition differences between grass species with regard to sodium are greater than those caused by any other element. Holcus lanatus, Lolium perenne and Anthoxantum odoratum contain on an average more sodium than Poa trivialis, Poa pratensis, Agrostis alba, Festuca rubra and Alopecurus pratensis. LEHR (1960) reports that, according to the rate of sodium uptake, species of grasses and Trifolium repens can be placed in the following order: Lolium perenne $>$ Trifolium repens $>$ Dactylis glomerata $>$ Poa trivialis $>$ Festuca pratensis $>$ Phleum pratense > Poa pratensis. VAN DER KLEY (1957) mentions large differences between sodium contents of grass species, clovers and herbs. BRUGGINK (1960) comes to the same conclusion. Garandeaux (1959) points out that differences exist in the sodium content of grass even within the species.

\section{Influence of soil fertility on the sodium content of meadow grass}

\subsection{Procedure}

The analytical results of the following investigations were used in order to study the influence of soil fertility on the sodium content of grass.

1. Trial fields laid down all over the Netherlands in 1958 and 1959 and conducted by OOSTENDORP (series 68).

2. A series of small experiments on sandy soils in 1952 conducted by VENEKAMP (Exp. 1326).

3. The "soil-plant-animal" investigations at Woudenberg (1957) and Borculo (1959). In these investigations soil and plant samples were taken in order to relate the results of analytical investigations to each other and also to animal health. 
4. In addition use was made of the analytical results of samples taken in re-allotments.

In re-allotments soils and plant samples are taken and analysed to obtain some idea of their fertility status.

In the investigations mentioned under 3 and 4 the soil and plant samples were collected at the same time; in those mentioned under 1 the soil samples were collected at the beginning of the experiments. In this research work the plant analyses only relate to the treatments without potash, and in investigation 4 the soil samples were taken after the first cut and only the results of the treatments without potash were taken into consideration.

Altogether we had at our disposal 208 samples of sandy soils, viz. 48 of the soilplant-animal investigation at Borculo, 95 samples of Woudenberg, 57 of Exp. 1326 and 8 of series 68 . There were 93 clay-soil samples, all taken from re-allotments.

Although we processed the results of all the investigations separately, for the sake of brevity we will first discuss the results of the S.P.A. investigation Borculo and then the results of the joint processing.

The results of the separate processing of all investigations has been published in Versl. Landbk. Onderz. (HENKENS and van LUIT, 1963).

\subsection{R e sults}

The considerable influence of potassium on the sodium uptake of the plant was mentioned above. FIG. 1 shows the correlation between the potassium and sodium contents of the grass. The sodium content decreases with increasing potassium content.

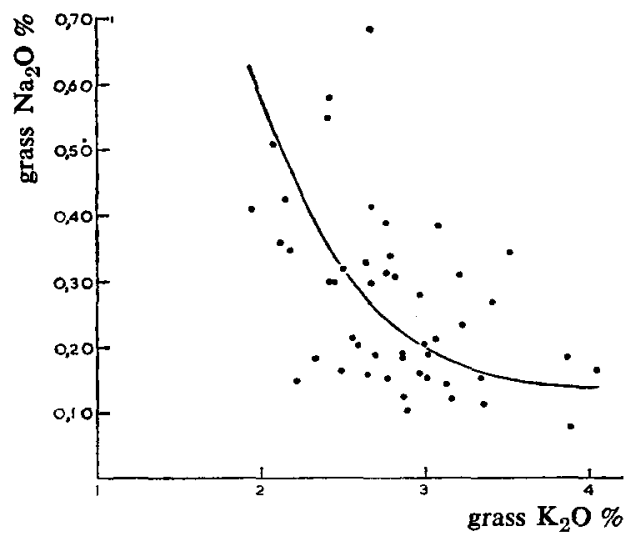

Fig. 1

Relation between potash and sodium contents of grass in the Borculo (1959) S.P.A. ${ }^{1}$ investigation

$1=$ Soil - Plant - Animal.

The potassium content of grass depends on the potash status of the soil. The potash status can be represented by the potassium content $(\mathrm{K}-\mathrm{HCl})^{1}$ or the $\mathrm{K}$-number ${ }^{2}$. VAN DER PAAUw (1953) stated that the K-number is a more reliable index of the potash status of the soil than $\mathrm{K}-\mathrm{HCl}$. This is also demonstrated in the present material. The advantage of the $\mathrm{K}$-number is that the humus content need not be taken into consideration in the interpretation. In this study we have therefore used the K-number.

$1 \mathrm{~K}-\mathrm{HCl}$ is the amount of $\mathrm{K}_{2} \mathrm{O}$ in the soil (in $1 / 1000 \%$ ) soluble in $1 / 10 \mathrm{~N} \mathrm{HCl}$.

$2 \mathrm{~K}$-number is the agricultural interpretation of $\mathrm{K}-\mathrm{HCl}$ in which the empirically assessed influence of the organic-matter content is taken into account. 
There is a correlation between $\mathrm{K}$-number of the soil and sodium content of the grass (FIG. 2). The scatter of the dots around the curve is caused by other factors and errors. To study the influence of other factors $(\mathrm{pH}$, organic-matter and sodium content of the soil and potassium and protein content of the grass) the vertical deviations of the dots from the average curve were plotted against these factors. The only influence found was that of the sodium content of the soil. In FIG. 3 the vertical deviations of the dots from the average curve in FIG. 2 at K-numbers $\leqslant 20$ are plotted against the sodium content ${ }^{1}$ of the soil. The same is done with the dots at K-numbers $>20$ (FIG. 4). Comparison of both figures shows that the influence of the sodium content of the soil at low $\mathrm{K}$-numbers is larger than at high $\mathrm{K}$-numbers.

The advantage of combining all analyses is that the interaction between the potash and sodium status of the soil in relation to the sodium uptake of grass can be better studied.

To study the influence of the sodium content of the soil on the sodium content of
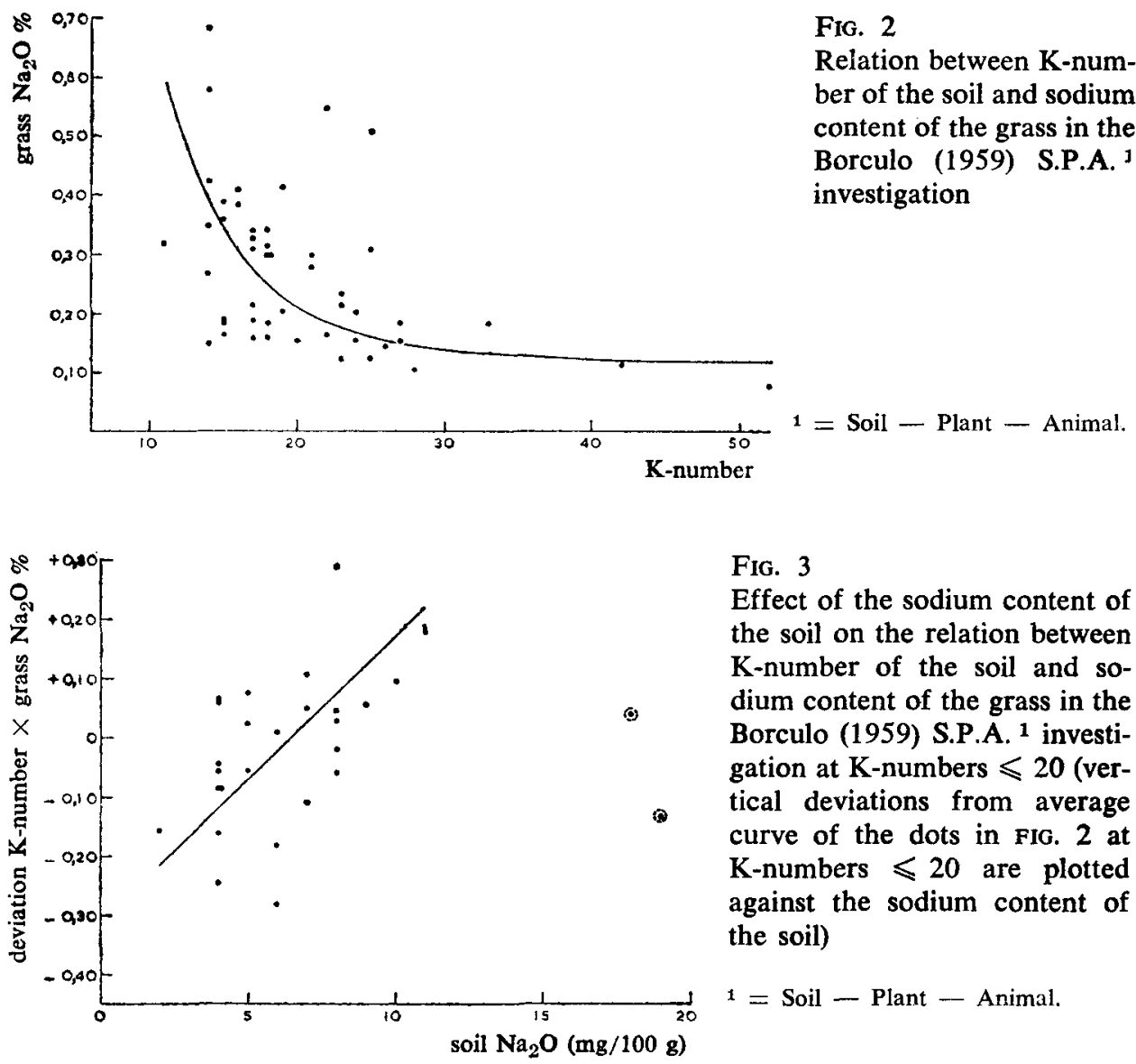

1 Sodium is the amount of $\mathrm{Na}_{2} \mathrm{O}$ soluble in $1 / 10 \mathrm{~N} \mathrm{HCl}$ in $\mathrm{mg} / 100 \mathrm{~g}$ of soil. 


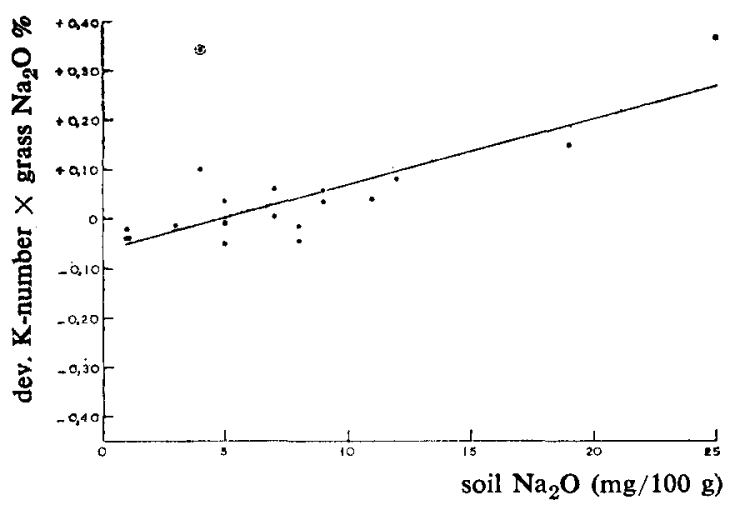

FIG. 4

Effect of the sodium content of the soil on the relation between $\mathrm{K}$ number of the soil and sodium content of the grass in the Borculo (1959) S.P.A. ${ }^{1}$ investigation at $\mathbf{K}$ numbers $>20$ (vertical deviations from average curve of the dots in FIG. 2 at K-numbers $>20$ are plotted against the sodium content of the soil)

$1=$ Soil - Plant - Animal.

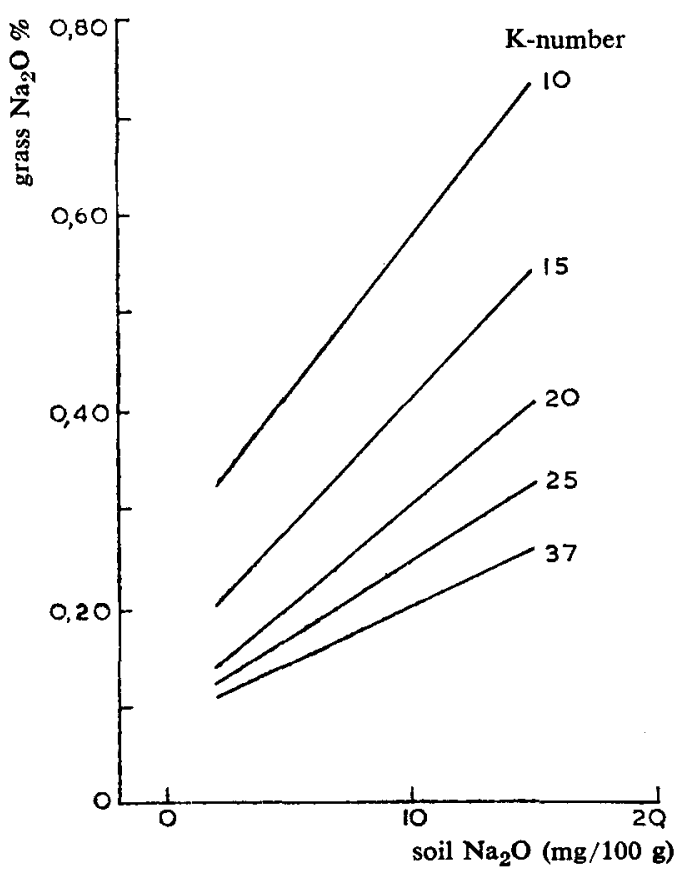

FIG. 5

Relation (adjusted) between sodium content of the soil and that of the grass on sandy soils at varying $\mathrm{K}$ numbers

the grass the analyses were therefore divided into groups with different K-numbers. Similarly, to study the influence of the K-number the analyses were divided into groups with different sodium content of the soil.

The adjusted relation between the $\mathrm{Na}_{2} \mathrm{O}$-contents of soil and grass at different $\mathrm{K}$ numbers is shown in FIG. 5. FIG. 6 shows the adjusted relation between $\mathrm{K}$-number of the soil and sodium content of the grass at different sodium contents of the soil.

Both figures show that an interaction exists between the sodium and the potash status of the soil with respect to the uptake of sodium by grass.

The relation between sodium status of the soil and sodium content of the grass suggests that the latter can increase to an unlimited extent with an increasing sodium status of the soil. But it should be noted that in this study there was only one soil 

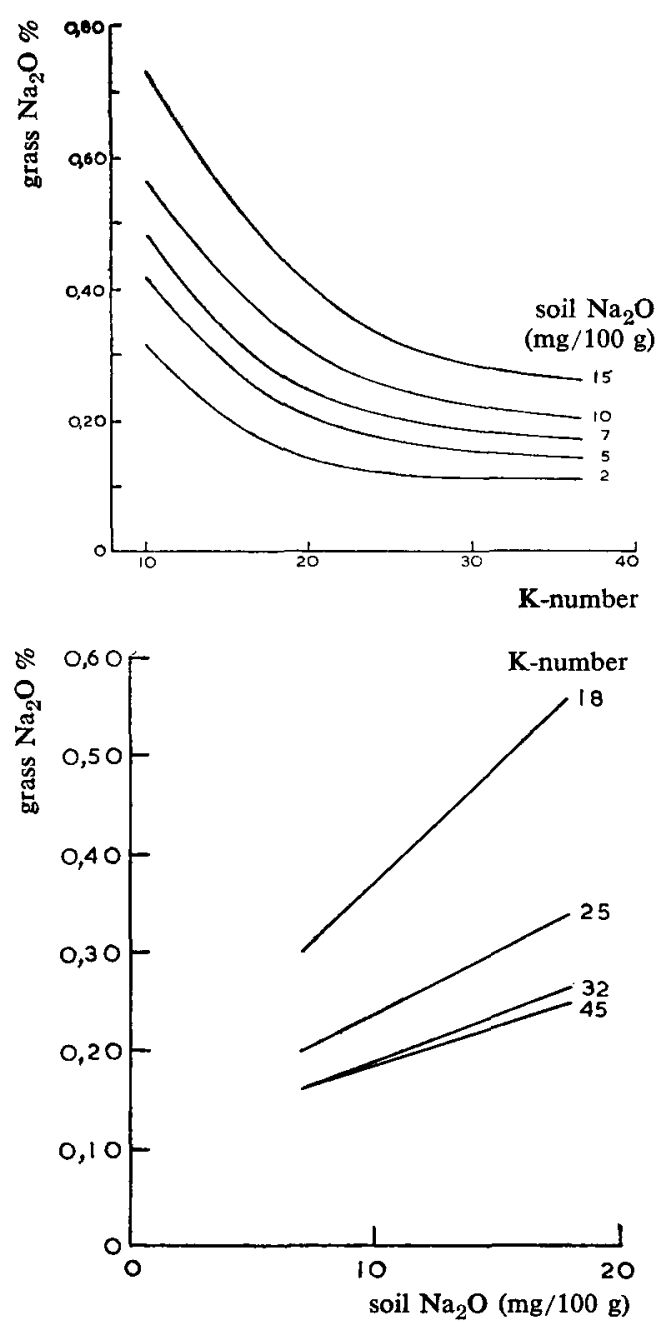

FIG. 6

Relation (adjusted) between $\mathrm{K}$-number of the soil and sodium content of the grass on sandy soils at varying sodium contents of the soil

\section{FIG. 7}

Relation (adjusted) between sodium content of the soil and sodium content of the grass on clay soils at varying K-numbers

sample with a sodium content higher than $20 \mathrm{mg} / 100 \mathrm{~g}$ of soil. Most of the soils analysed had sodium-content values below 10 . It is unlikely that the rectilinear curve would still be found at the high sodium levels of the soil.

FIG. 6 shows that when the K-number of the soil exceeds a value of 26 at low sodium levels, there is no further decrease in the sodium content of the grass. But higher K-numbers have still an effect at higher sodium levels of the soil. We would therefore appear justified in concluding that $\mathrm{K}$-numbers higher than 30 only have a negligible influence on the sodium content of the grass. This conclusion is also supported by an investigation of VAN DER PAAUW (1956) who pointed out that K-numbers higher than 30 hardly increase the potash content of grass.

On clay soils (analyses of re-allotments) there is also a clear interaction between the sodium and the potassium status of the soil with respect to the sodium uptake of the grass (FIG. 7 and 8). As in sandy soils, potassium also has a negligible influence on 


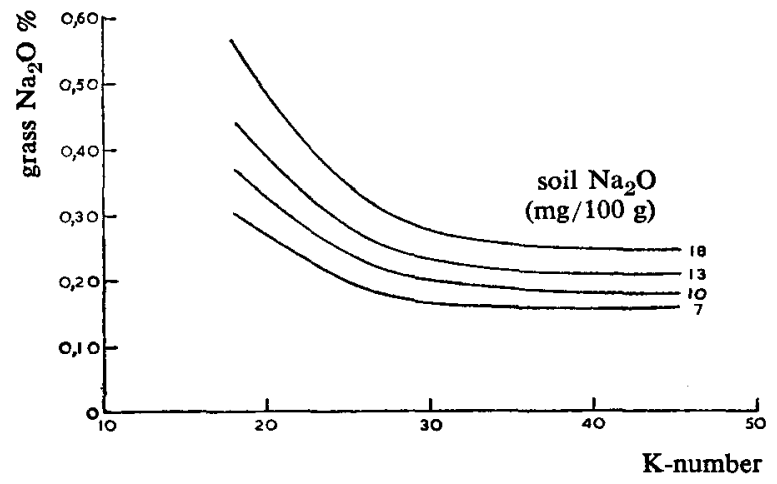

Fig. 8

Relation (adjusted) between Knumber of the soil and sodium content of the grass on clay soils at varying sodium contents of the soil

the sodium content of grass in clay soils with K-numbers higher than 30 .

As $\mathrm{K}$-numbers above 30 only have a negligible effect on the sodium content of grass, the soil-sodium content is important in sodium-fertiliser recommendations. With the present potassium-fertiliser policy in the Netherlands the K-number is generally raised to a level at which it has a virtually constant effect on the sodium content of grass. In the case of sandy soils the effect of potassium and sodium status of the soil on the sodium content of grass can both be expressed by means of the ratio $\frac{15 \mathrm{~K} \text {-number }}{\mathrm{Na}_{2} \mathrm{O}+6}$ and in the case of clay soils by $\frac{25 \mathrm{~K} \text {-number }}{\mathrm{Na}_{2} \mathrm{O}+14}$. These ratios are calculated by a method described by VAN DER PAAUW and RIS (1960) which is mainly applicable at lower K-numbers.

It is found (FIG. 5 and 6) that a difference of 1 unit in the soil- $\mathrm{Na}_{2} \mathrm{O}$ content has an effect similar to that of a difference of $1,2 \mathrm{~K}$-number units, in the range of $\mathrm{K}$-numbers between 12,1 and 16,0 (average $\mathrm{K}$-number equals 14,5 and average soil- $\mathrm{Na}{ }_{2} \mathrm{O}$ content equals 6,0 ). If the $\mathrm{Na}_{2} \mathrm{O}$ content of the soil differs from 6,0 , the $\mathrm{K}$-number $(14,5)$ can be corrected with the use of the correction factor $1,2\left(6,0-\right.$ soil- $\mathrm{Na}_{2} \mathrm{O}$ content in $\left.0,001 \%\right)$. Since soil- $\mathrm{Na}$ has a positive effect on the $\mathrm{Na}$-content of pasture, at any soil- $\mathrm{Na}_{2} \mathrm{O}$ content the evaluation of a $\mathrm{K}$-number equal to 14,5 ( soil- $\mathrm{Na}_{2} \mathrm{O}$ content $=6,0$ ) may be the same as that of a $\mathrm{K}$-number equal to $14,5-1,2\left(6,0-\mathrm{Na}_{2} \mathrm{O}\right.$ ). Assuming the ratio of these $\mathrm{K}$-numbers to be valid beyond the range 12,1 to 16,0 , the following ratio can be given characterising the $\mathrm{Na}$-status of the soil : $\frac{14,5}{14,5-1,2\left(6,0-\mathrm{Na}_{2} \overline{\mathrm{O}}\right)} \times \mathrm{K}$-number $=$
$12,1 \times \mathrm{K}$-number $\frac{12,1 \times \mathrm{K} \text {-number }}{\mathrm{Na} \mathrm{O}+6,1}$

$\mathrm{Na}_{2} \mathrm{O}+6,1$
The coefficient of the numerator is not essential, and for practical reasons, the ratio $\frac{15}{\mathrm{Na}_{2} \mathrm{O}}+\frac{\mathrm{K} \text {-number }}{6}$ will be used. This assumption also proved acceptable in the range of $K$-numbers between 16,1 and 20,0 .

Since there were too few observations, it was not possible to verify whether these ratios are exact at high K-numbers. Moreover, there is much doubt about the validity of these ratios at high potash numbers, since the decrease in the $\mathrm{Na}_{2} \mathrm{O}$-content of the grass caused by $\mathbf{K}$-numbers above 30 is negligible (even before this at lower sodium contents of the soil). This means that at K-numbers higher than 30 it is no longer permissible to use the product as numerator (i.e. $15 \times$ and $25 \times \mathrm{K}$-number respectively) but it should have the same value as at $\mathrm{K}$-number 30 (i.e. 450 for sandy soils and 750 for clay soils). 

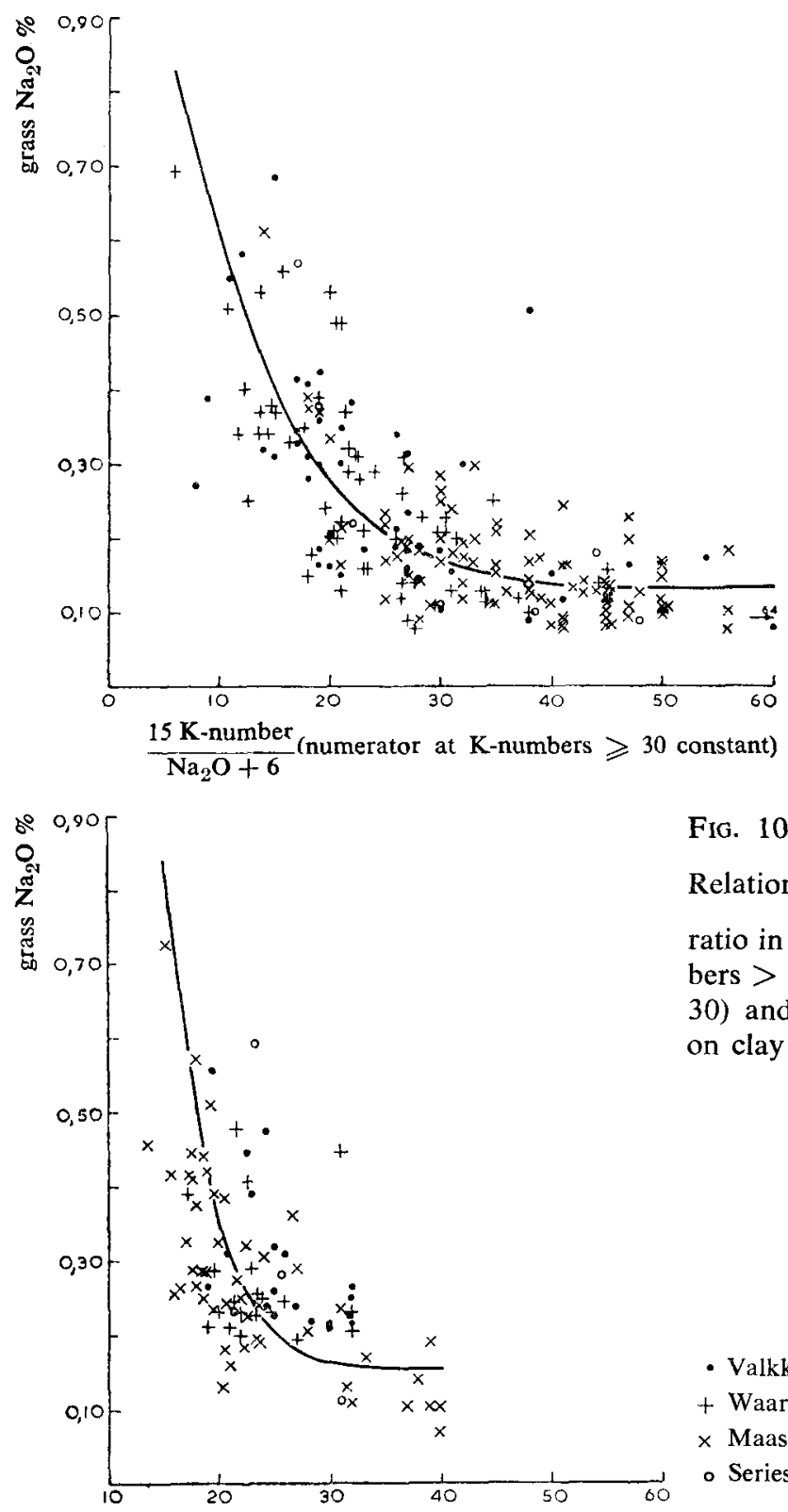

$\frac{25 \mathrm{~K} \text {-number }}{\mathrm{Na}_{2} \mathrm{O}+14}$ (numerator at K-numbers $\geqslant 30$

FIg. 10
FIG. 9

Relation between the $15 \mathrm{~K}$-number $\mathrm{Na}_{2} \mathrm{O}+6$ ratio in the soil (numerator at K-numbers $>30$ is the same as at $\mathrm{K}$ number 30 ) and the sodium content of grass on sandy soils
- S.P.A. Borculo

+ Exp. 1326

$\times$ S.P.A. Woudenberg

- Series 68

Relation between the $\frac{25 \mathrm{~K} \text {-number }}{\mathrm{Na} 2 \mathrm{O}+14}$ ratio in the soil (numerator at K-numbers $>30$ is the same as at K-number $30)$ and the sodium content of grass on clay soils

- Valkkoog

+ Waarland

$\times$ Maas en Waal

- Series 68

Fig. 9 and 10 show the correlation between the sodium content of the grass and the ratio $\frac{15 \mathrm{~K} \text {-number }}{\mathrm{Na} 2 \mathrm{O}+6}$ and $\frac{25 \mathrm{~K} \text {-number }}{\mathrm{Na} 2 \mathrm{O}+14}$ respectively when the numerators at $\mathrm{K}$-numbers 
higher than 30 have constant values. It can be seen from both figures that the sodium content of grass decreases with increasing ratios.

\section{Influence of fertilisers on the sodium content of meadow grass}

\subsection{Potash fertilisers}

It may be expected that potash fertilisers will only influence the sodium content of grass at lower $\mathrm{K}$-numbers as the sodium content of grass is not affected by very high $\mathrm{K}$-numbers. The differences between the sodium contents of grass on plots without potash and those with a potash dressing of $200 \mathrm{~kg} \mathrm{~K} \mathrm{~K}_{2} \mathrm{O} / \mathrm{ha}$ (in the form of $60 \%$ potash salt) on the Exp. 1326 series of trial fields were plotted against the K-numbers of the plots without potash dressing (FIG. 11). This figure shows that the sodium content of grass is reduced by potash dressing at a low $\mathrm{K}$-number of the soil, irrespective of low or high sodium status.

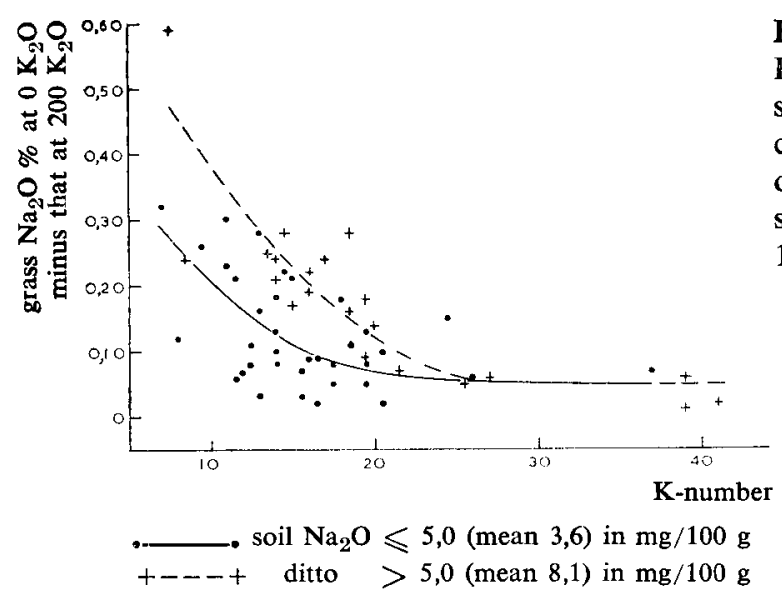

FIG. 11

Relation between $\mathrm{K}$-number of the soil and decrease of the sodium content of the grass by a dressing of $200 \mathrm{~kg} \mathrm{~K}{ }_{2} \mathrm{O}$ per ha (60\% potash salt) at two sodium levels at Exp. 1326 (1952)

The part played by the sodium content in the different potash salts may also be assessed in this connection. In our opinion the influence of a certain amount of sodium in potash fertilisers depends on the ratios $\frac{15 \mathrm{~K} \text {-number }}{\mathrm{Na} 2 \mathrm{O}+6}$ and $\frac{25 \mathrm{~K} \text {-number }}{\mathrm{Na}_{2} \mathrm{O}+14}$ in the case of sandy and clay soils respectively. At a low ratio (i.e. a high sodium content of grass) we expect the sodium in potash fertilisers to be incapable of counterbalancing the decrease in sodium content of the grass caused by potash, while at a high ratio (i.e. a low sodium content in the grass) the sodium in potash fertilisers may even increase the sodium content of grass.

This is shown in TABLE 1 which sets forth the sodium content of grass at different ratios in the soil of the trial fields of the series 71 and 68 without potash and with a dressing of $100 \mathrm{~kg} \mathrm{~K} 2 \mathrm{O} / \mathrm{ha}$ (in the form of $40 \%$ potash salt). $40 \%$ potash salt normally contains $7-18 \% \mathrm{Na}_{2} \mathrm{O}$; the sodium content of the salt used in these experiments had not been determined. TABLE 1 shows that the dressing of $40 \%$ potash salt resulted in a reduction in the sodium content of the grass on sandy and clay soils when the ratios $\frac{15 \mathrm{~K} \text {-number }}{\mathrm{Na}_{2} \mathrm{O}+6}$ and $\frac{25 \mathrm{~K} \text {-number }}{\mathrm{Na}_{2} \mathrm{O}+14}$ are below $20-30$. This reduction is 
TABLE 1. Na $\mathrm{Na}_{2} \mathrm{O}$-content of grass with and without potash dressing (in the form of $40 \%$ potash salt) at varying $\frac{15 \mathrm{~K} \text {-number }}{\mathrm{Na}_{2} \mathrm{O}+\overline{6}}$ ratios on sandy soils and

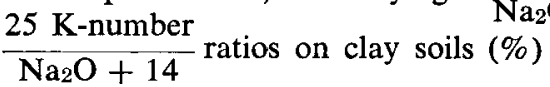

\begin{tabular}{|c|c|c|c|c|c|c|}
\hline \multirow[t]{3}{*}{ Ratio } & \multicolumn{6}{|c|}{$\mathrm{Na}_{2} \mathrm{O}$-content of grass $(\%)$} \\
\hline & \multicolumn{3}{|c|}{ series 71} & \multicolumn{3}{|c|}{ series 68} \\
\hline & $0 \mathrm{~kg} \mathrm{~K}_{2} \mathrm{O} / \mathrm{ha}$ & $100 \mathrm{~kg} \mathrm{~K}_{2} \mathrm{O} / \mathrm{ha}$ & $\begin{array}{c}\text { No. of } \\
\text { samples }\end{array}$ & $0 \mathrm{~kg} \mathrm{~K}_{2} \mathrm{O} / \mathrm{ha}$ & $100 \mathrm{~kg} \mathrm{~K}_{2} \mathrm{O} / \mathrm{ha}$ & $\begin{array}{c}\text { No. of } \\
\text { samples }\end{array}$ \\
\hline \multicolumn{7}{|c|}{ Sandy soils } \\
\hline$\leqslant 20$ & 0,72 & 0,44 & 2 & 0,48 & 0,35 & 2 \\
\hline $21-30$ & 0,24 & 0,21 & 6 & 0,17 & 0,19 & 2 \\
\hline $31-40$ & 0,21 & 0,22 & 8 & 0,12 & 0,15 & 2 \\
\hline$>40$ & 0,10 & 0,19 & 6 & 0,14 & 0,13 & 2 \\
\hline \multicolumn{7}{|c|}{ Clay soils } \\
\hline$\leqslant 20$ & 0,52 & 0,38 & 6 & - & - & - \\
\hline $21-30$ & 0,36 & 0,25 & 5 & 0,31 & 0,23 & 4 \\
\hline $31-40$ & 0,19 & 0,19 & 7 & 0,11 & 0,14 & 1 \\
\hline
\end{tabular}

TABLE 2. Influence of potash dressing with two different amounts of nitrogen on the sodium

\begin{tabular}{|c|c|c|c|c|c|c|c|c|c|c|}
\hline \multirow[t]{3}{*}{ Treatment } & \multicolumn{4}{|c|}{ Ist cut } & \multicolumn{4}{|c|}{ 2nd cut } & \multirow{2}{*}{\multicolumn{2}{|c|}{$\frac{3 \mathrm{rd} \text { cut }}{40 \mathrm{~kg} \mathrm{~N}}$}} \\
\hline & \multicolumn{2}{|c|}{$40 \mathrm{~kg} \mathrm{~N}$} & \multicolumn{2}{|c|}{$80 \mathrm{~kg} \mathrm{~N}$} & \multicolumn{2}{|c|}{$40 \mathrm{~kg} \mathrm{~N}$} & \multicolumn{2}{|c|}{$80 \mathrm{~kg} \mathrm{~N}$} & & \\
\hline & $\mathrm{K}_{2} \mathrm{O}$ & $\mathrm{Na}_{2} \mathrm{O}$ & $\mathrm{K}_{2} \mathrm{O}$ & $\mathrm{Na}_{2} \mathrm{O}$ & $\mathrm{K}_{2} \mathrm{O}$ & $\mathrm{Na}_{2} \mathrm{O}$ & $\mathrm{K}_{2} \mathrm{O}$ & $\mathrm{Na}_{2} \mathrm{O}$ & $\mathrm{K}_{2} \mathrm{O}$ & $\mathrm{Na}_{2} \mathrm{O}$ \\
\hline \multicolumn{11}{|l|}{ Year 1954} \\
\hline $0 \mathrm{~kg} \mathrm{~K} \mathrm{~K}_{2} \mathrm{O} / \mathrm{ha}$ & 2,14 & 0,50 & 2,07 & 0,49 & 1,88 & 0,71 & 2,20 & 0,47 & 1,73 & 0,80 \\
\hline $400 \mathrm{~kg} \mathrm{~K} \mathrm{~K}_{20}\left(80 \mathrm{~kg} \mathrm{~K} \mathrm{~K}_{2} \mathrm{O} / \mathrm{ha}\right)$ & 2,59 & 0,43 & 2,71 & 0,35 & 3,36 & 0,50 & 3,59 & 0,38 & 3,37 & 0,66 \\
\hline $200 \mathrm{~kg} \mathrm{~K}_{40}\left(80 \mathrm{~kg} \mathrm{~K}_{2} \mathrm{O} / \mathrm{ha}\right)$ & 2,71 & 0,36 & 2,52 & 0,3 & 3,58 & 0,42 & 3,29 & 0 & 3,35 & 0,36 \\
\hline $\begin{array}{l}135 \mathrm{~kg} \mathrm{~K}_{60}(80 \mathrm{~kg} \mathrm{~K} \\
470 \mathrm{~kg} \text { kainite }\end{array}$ & 3,01 & 0,46 & 2,34 & 0,36 & 3,63 & 0,44 & 3,37 & 0,28 & 3,57 & 0,46 \\
\hline $\begin{array}{r}\left(80 \mathrm{~kg} \mathrm{~K} \mathrm{~K}_{2} \mathrm{O} / \mathrm{ha}\right) \\
300 \mathrm{~kg} \text { sulphate of potash }\end{array}$ & 2,58 & 0,44 & 2,53 & 0,35 & 3,29 & 0,53 & 3,46 & 0,31 & 3,52 & 0,59 \\
\hline $\begin{array}{l}300 \mathrm{~kg} \text { sulphate of potash } \\
\left.\text { magnesia ( } 80 \mathrm{~kg} \mathrm{~K} \mathrm{~K}_{2} \mathrm{O} / \mathrm{ha}\right)\end{array}$ & 2,58 & 0,36 & 2,59 & 0,32 & 3,67 & 0,32 & 3,57 & 0,28 & 3,78 & 0,42 \\
\hline mean & 2,60 & 0,43 & 2,46 & 0,37 & 3,24 & 0,49 & 3,25 & 0,34 & 3,22 & 0,55 \\
\hline \multicolumn{11}{|l|}{ Year 1955} \\
\hline $0 \mathrm{~kg} \mathrm{~K} \mathrm{~K}_{2} \mathrm{O} / \mathrm{ha}$ & 1,78 & 0,75 & 1,36 & 0,77 & 1,24 & 0,61 & 1,24 & 7 & 1,18 & 0,67 \\
\hline $400 \mathrm{~kg} \mathrm{~K}_{20}\left(80 \mathrm{~kg} \mathrm{~K}_{2} \mathrm{O} / \mathrm{ha}\right)$ & 3,06 & 0,4 & 3,13 & 0 & 3,07 & 0,42 & 2,83 & & 2,94 & 0,51 \\
\hline $200 \mathrm{~kg} \mathrm{~K}_{\mathbf{4 0}}\left(80 \mathrm{~kg} \mathrm{~K} \mathrm{~K}_{2} \mathrm{O} / \mathrm{ha}\right)$ & 2,94 & 0,36 & 2,84 & 0,4 & - & - & 3,0 & 1 & 2,84 & 0,44 \\
\hline $\begin{array}{l}135 \mathrm{~kg} \mathrm{~K}_{60}(80 \mathrm{~kg} \mathrm{~K} \\
470 \mathrm{~kg} \text { kainite }\end{array}$ & 2,86 & 0,32 & 2,73 & 0,46 & 3,01 & 0,34 & 2,63 & 0,53 & 2,52 & 0,36 \\
\hline $\begin{array}{r}\left(80 \mathrm{~kg} \mathrm{~K} \mathrm{~K}_{2} \mathrm{O} / \mathrm{ha}\right) \\
300 \mathrm{~kg} \text { sulphate of potash }\end{array}$ & 3,04 & 0,38 & 2,82 & 0,54 & 2,94 & 0,36 & 3,23 & 0,54 & 2,63 & 0,43 \\
\hline magnesia $\left(80 \mathrm{~kg} \mathrm{~K} \mathrm{~K}_{2} \mathrm{O} / \mathrm{ha}\right)$ & 2,81 & 0,32 & 2,84 & 0,40 & 2,70 & 0,35 & 2,79 & 0,47 & 2,63 & 0,47 \\
\hline mean $\ldots \ldots \ldots \ldots \ldots$ & 2,75 & 0,43 & 2,62 & 0,53 & 2,59 & 0,42 & 2,62 & 0,58 & 2,46 & 0,48 \\
\hline \multicolumn{11}{|l|}{ Year 1956} \\
\hline $0 \mathrm{~kg} \mathrm{~K}_{2} \mathrm{O} / \mathrm{ha}$ & 0,90 & 0,6 & 0,88 & 0 & 1,00 & 07 & 082 & 0 & 0,89 & 0,63 \\
\hline $400 \mathrm{~kg} \mathrm{~K}_{20}\left(80 \mathrm{~kg} \mathrm{~K}_{2} \mathrm{O} / \mathrm{ha}\right)$ & 2,5 & & & & & & 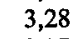 & & 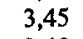 & 0 , \\
\hline $200 \mathrm{~kg} \mathrm{~K}_{40}(80 \mathrm{~kg} \mathrm{~K} 2 \mathrm{O} / \mathrm{ha})$ & 2,29 & 0,31 & 2,31 & 0,40 & 3,13 & 0,42 & 3,07 & 0,55 & 3,43 & 0,35 \\
\hline $\begin{array}{l}135 \mathrm{~kg} \mathrm{~K} \mathrm{~K}_{60}\left(80 \mathrm{~kg} \mathrm{~K} \mathrm{~K}_{2} \mathrm{O} / \mathrm{ha}\right) \\
470 \mathrm{~kg} \text { kainite }\end{array}$ & 2,61 & 0,30 & 2,29 & 0,3 & 3,12 & 0,30 & 3,34 & 0,39 & 3,46 & 0,34 \\
\hline$\left(80 \mathrm{~kg} \mathrm{~K}_{2} \mathrm{O} / \mathrm{ha}\right)$ & 2,32 & 0 , & 2,36 & 0,34 & 2,90 & 0,46 & 2,98 & 0,59 & 3,18 & 0,40 \\
\hline $\begin{array}{l}300 \mathrm{~kg} \text { sulphate of potash } \\
\text { magnesia }\left(80 \mathrm{~kg} \mathrm{~K} \mathrm{~K}_{2} \mathrm{O} / \mathrm{ha}\right)\end{array}$ & 2,54 & 0,31 & 2,11 & 0,28 & 3,16 & 0,34 & 3,11 & 0,31 & 3,13 & 0,28 \\
\hline mean & 2,20 & 0,36 & 2,05 & 0,37 & 2,72 & 0,45 & 2,77 & 0,50 & 2,92 & 0,40 \\
\hline
\end{tabular}


not harmful, however, since the sodium content of the grass is high at both ratios. As pointed out earlier, with ratios above 40 a dressing with $40 \%$ potash salt led to an increase in the sodium content of the grass.

The Netherlands Potash Import Company was kind enough to place the results of their trial fields at our disposal. In one of these the influence was studied of a dressing with $80 \mathrm{~kg} \mathrm{~K} \mathrm{~K}_{2} \mathrm{O} / \mathrm{ha}$ (in the form of $20 \%, 40 \%$ and $60 \%$ potash salt, kainite and sulphate of potash-magnesia) with 40 and $80 \mathrm{~kg} \mathrm{~N} / \mathrm{ha}$ (in the form of ammoniumnitrate limestone). The sodium content of the treatment without potash was found to be high, indicating the $\frac{25 \mathrm{~K} \text {-number }}{\mathrm{Na} 2 \mathrm{O}+14}$ ratio in the soil to be low (the experiments were laid down on a clay soil with a peaty subsoil). The results set out in TABLE 2 and FIG. 12, 13 and 14, show that the sodium content of grass was reduced by all kinds of potash fertilisers, which is in agreement with the results given in TABLE 1 . The reduction is lowest with fertilisers containing fairly large amounts of sodium (20\% potash salt and kainite). The difference between $40 \%$ and $60 \%$ potash salt and sulphate of potash magnesia is only slight and not consistent. It is known that the sodium content of $40 \%$ potash salt may be somewhat variable (7-18\% $\left.\mathrm{Na}_{2} \mathrm{O}\right)$. Unfortunately, the fertilisers had not been analysed.

and potassium contents of grass in 1954,1955 and $1956(\%)$

\begin{tabular}{|c|c|c|c|c|c|c|c|c|c|c|c|c|c|}
\hline \multirow{2}{*}{\multicolumn{2}{|c|}{$\frac{3 \mathrm{rd} \mathrm{cut}}{80 \mathrm{~kg} \mathrm{~N}}$}} & \multicolumn{4}{|c|}{ 4th cut } & \multicolumn{4}{|c|}{ 5th cut } & \multicolumn{4}{|c|}{ Mean } \\
\hline & & \multicolumn{2}{|c|}{$40 \mathrm{~kg} \mathrm{~N}$} & \multicolumn{2}{|c|}{$80 \mathrm{~kg} \mathrm{~N}$} & \multicolumn{2}{|c|}{$40 \mathrm{~kg} \mathrm{~N}$} & \multicolumn{2}{|c|}{$80 \mathrm{~kg} \mathrm{~N}$} & \multicolumn{2}{|c|}{$40 \mathrm{~kg} \mathrm{~N}$} & \multicolumn{2}{|c|}{$80 \mathrm{~kg} \mathrm{~N}$} \\
\hline $\mathrm{K}_{2} \mathrm{O}$ & $\mathrm{Na}_{2} \mathrm{O}$ & $\mathrm{K}_{2} \mathrm{O}$ & $\mathrm{Na}_{2} \mathrm{O}$ & $\mathrm{K}_{2} \mathrm{O}$ & $\mathrm{Na}_{2} \mathrm{O}$ & $\mathrm{K}_{2} \mathrm{O}$ & $\mathrm{Na}_{2} \mathrm{O}$ & $\mathrm{K}_{2} \mathrm{O}$ & $\mathrm{Na}_{2} \mathrm{O}$ & $\mathrm{K}_{2} \mathrm{O}$ & $\mathrm{Na}_{2} \mathrm{O}$ & $\mathrm{K}_{2} \mathrm{O}$ & $\mathrm{Na}_{2} \mathrm{O}$ \\
\hline 1,93 & 0,61 & 1,31 & 0,69 & 1,37 & 0,59 & 1,20 & 0,63 & 1,93 & 0,44 & 1,65 & 0,67 & 1,90 & 0,52 \\
\hline 3,52 & 0,39 & 3,61 & 0,53 & 3,83 & 0,39 & 3,20 & 0,40 & 3,57 & 0,30 & 3,23 & 0,50 & 3,44 & 0,36 \\
\hline 3,47 & 0,34 & 4,07 & 0,38 & 4,08 & 0,27 & 3,32 & 0,36 & 3,32 & 0,27 & 3,41 & 0,37 & 3,34 & 0,31 \\
\hline 3,28 & 0,31 & 4,10 & 0,36 & 4,06 & 0,19 & 3,19 & 0,31 & 3,47 & 0,22 & 3,50 & 0,41 & 3,30 & 0,27 \\
\hline 3,48 & 0,55 & 4,28 & 0,44 & 3,95 & 0,28 & 3,57 & 0,34 & 3,57 & 0,30 & 3,45 & 0,47 & 3,40 & 0,36 \\
\hline 3,65 & 0,34 & 3,82 & 0,32 & 4,14 & 0,19 & 3,57 & 0,28 & 3,58 & 0,28 & 3,48 & 0,34 & 3,51 & 0,28 \\
\hline 3,22 & 0,42 & 3,53 & 0,45 & 3,57 & 0,32 & 3,01 & 0,39 & 3,24 & 0,30 & & & & \\
\hline 0,76 & 0,67 & 1,36 & 0,67 & 1,05 & 0,73 & 1,76 & 0,65 & 1,07 & 0,75 & 1,46 & 0,67 & 1,10 & 0,73 \\
\hline 2,76 & 0,81 & 3,02 & 0,59 & 3,07 & 0,69 & 2,95 & 0,44 & 3,23 & 0,61 & 3,01 & 0,48 & 3,00 & 0,68 \\
\hline 2,63 & 0,73 & 2,92 & 0,57 & 3,00 & 0,67 & 3,24 & 0,44 & 3,28 & 0,54 & 2,99 & 0,45 & 2,95 & 0,58 \\
\hline 2,49 & 0,58 & 2,93 & 0,42 & 2,96 & 0,57 & 3,35 & 0,38 & 2,79 & 0,51 & 2,93 & 0,36 & 2,72 & 0,53 \\
\hline 2,65 & 0,67 & 2,83 & 0,49 & 2,98 & 0,62 & 3,04 & 0,44 & 3,37 & 0,54 & 2,90 & 0,42 & 3,01 & 0,58 \\
\hline 2,57 & 0,65 & 2,92 & 0,49 & 2,99 & 0,59 & 3,55 & 0,36 & 3,14 & 0,51 & 2,92 & 0,40 & 2,87 & 0,52 \\
\hline 2,31 & 0,69 & 2,06 & 0,54 & 2,68 & 0,65 & 2,98 & 0,45 & 2,81 & 0,58 & & & & \\
\hline 0,76 & 0,51 & 0,67 & 0,65 & 0,67 & 0,54 & 0,77 & 0,65 & 0,90 & 0,55 & 0,85 & 0,66 & 0,81 & 0,55 \\
\hline 3,24 & 0,40 & 2,99 & 0,44 & 3,00 & 0,51 & 3,25 & 0,46 & 3,23 & 0,46 & 3,04 & 0,42 & 3,02 & 0,45 \\
\hline 3,10 & 0,40 & 3,19 & 0,38 & 2,95 & 0,49 & 3,90 & 0,39 & 3,72 & 0,47 & 3,19 & 0,37 & 3,03 & 0,46 \\
\hline 3,23 & 0,26 & 3,48 & 0,32 & 3,00 & 0,35 & 4,02 & 0,34 & 3,48 & 0,34 & 3,34 & 0,32 & 3,07 & 0,33 \\
\hline 3,18 & 0,38 & 2,70 & 0,38 & 2,76 & 0,46 & 3,25 & 0,47 & 3,24 & 0,53 & 2,87 & 0,39 & 2,90 & 0,46 \\
\hline 3,06 & 0,28 & 3,47 & 0,24 & 3,08 & 0,34 & 3,70 & 0,34 & 3,48 & 0,38 & 3,20 & 0,30 & 2,97 & 0,32 \\
\hline 2,76 & 0,37 & 2,75 & 0,40 & 2,58 & 0,45 & 3,15 & 0,44 & 3,01 & 0,46 & & & & \\
\hline
\end{tabular}


FIG. 12. Influence of potash dressing with two different amounts of nitrogen on the sodium content of grass in 1954

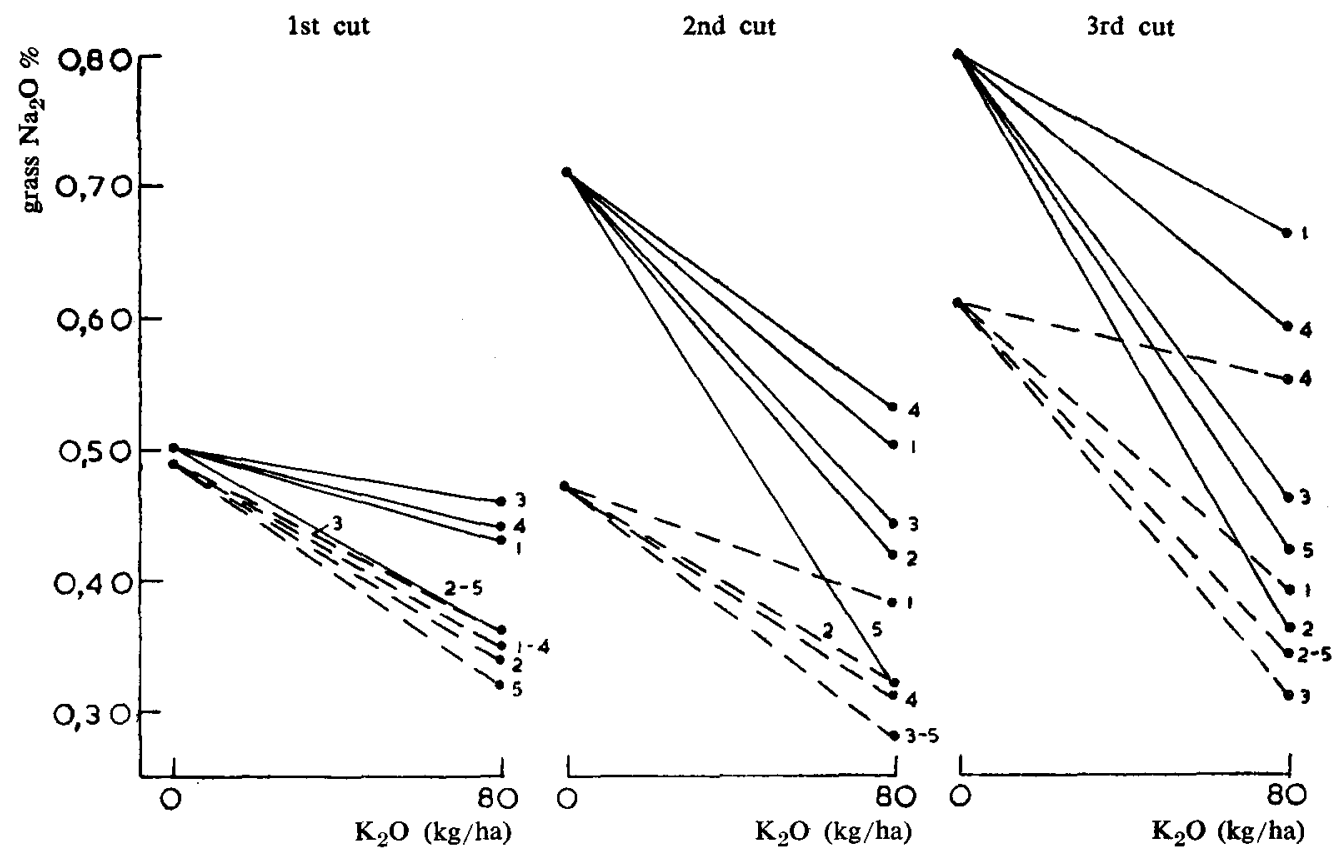

4th cut

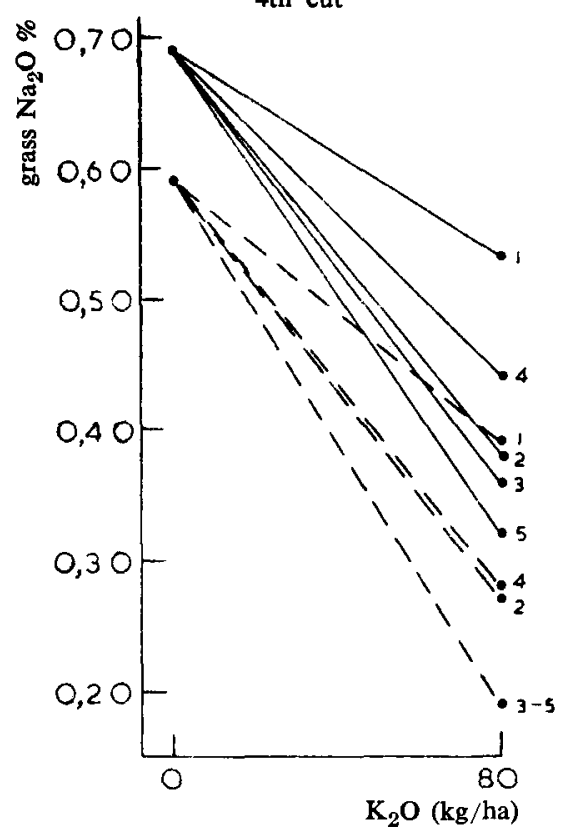

5th cut

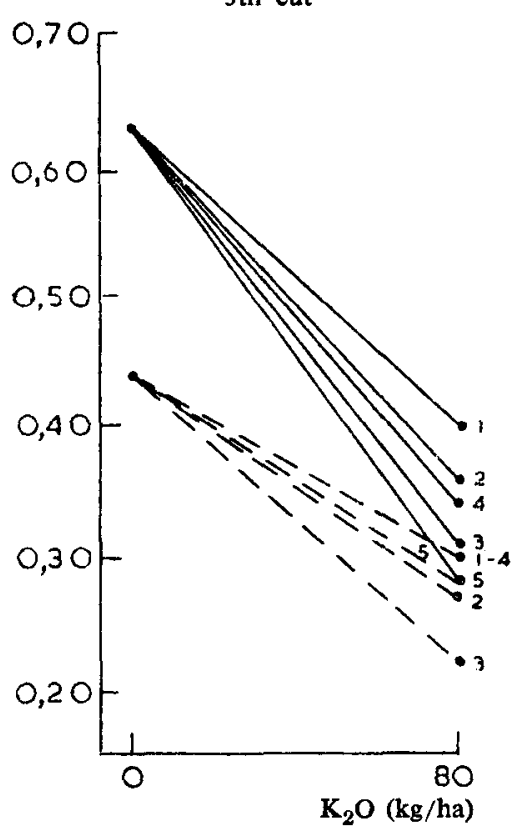

$120 \%$ potash salt

$240 \%$ " " $40 \mathrm{~kg} \mathrm{~N} / \mathrm{ha}$

5 sulphate of potash magnesia

$360 \%$ " "

4 kainite 
Fig. 13. Influence of potash dressing with two different amounts of nitrogen on the sodium content of grass in 1955
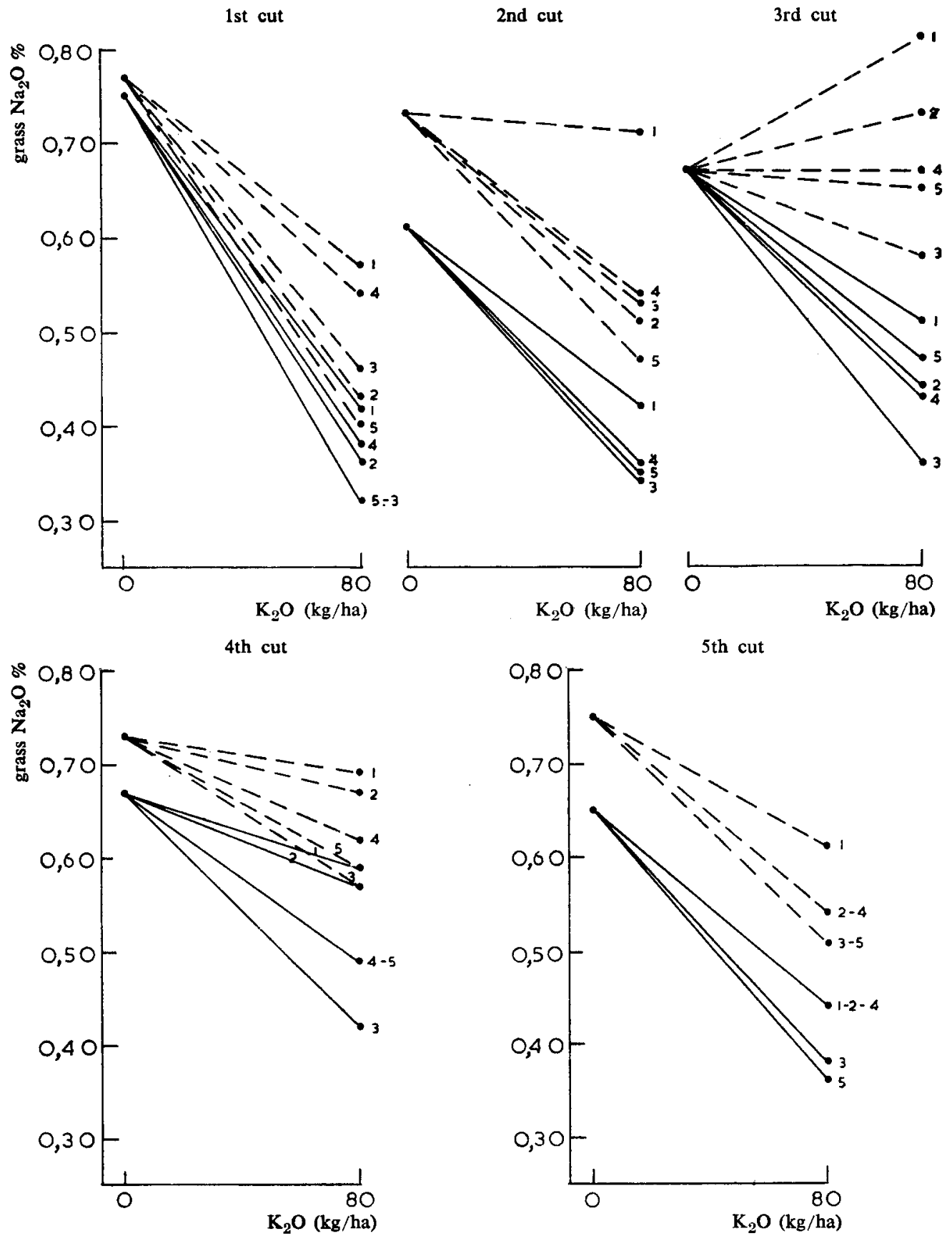

$120 \%$ potash salt

$240 \%$ " "

5 sulphate of potash magnesia

$360 \%$ "

4 kainite " " -20 " 
Fig. 14. Influence of potash dressing with two different amounts of nitrogen on the sodium content of grass in 1956
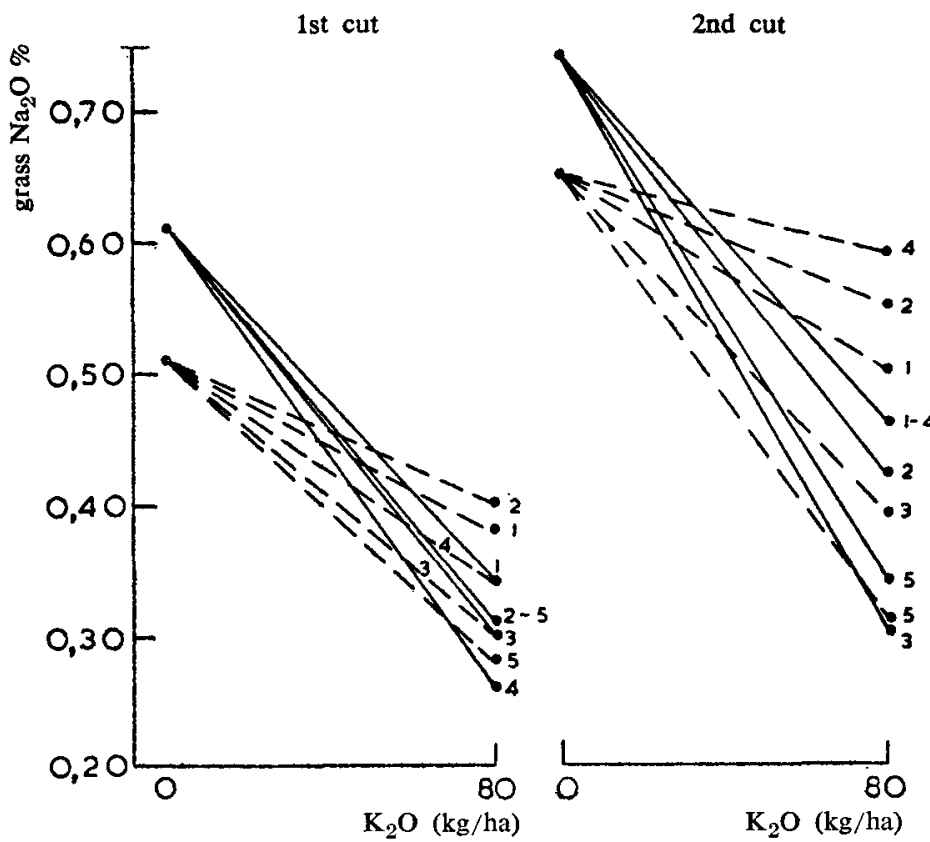

3rd cut

4th cut
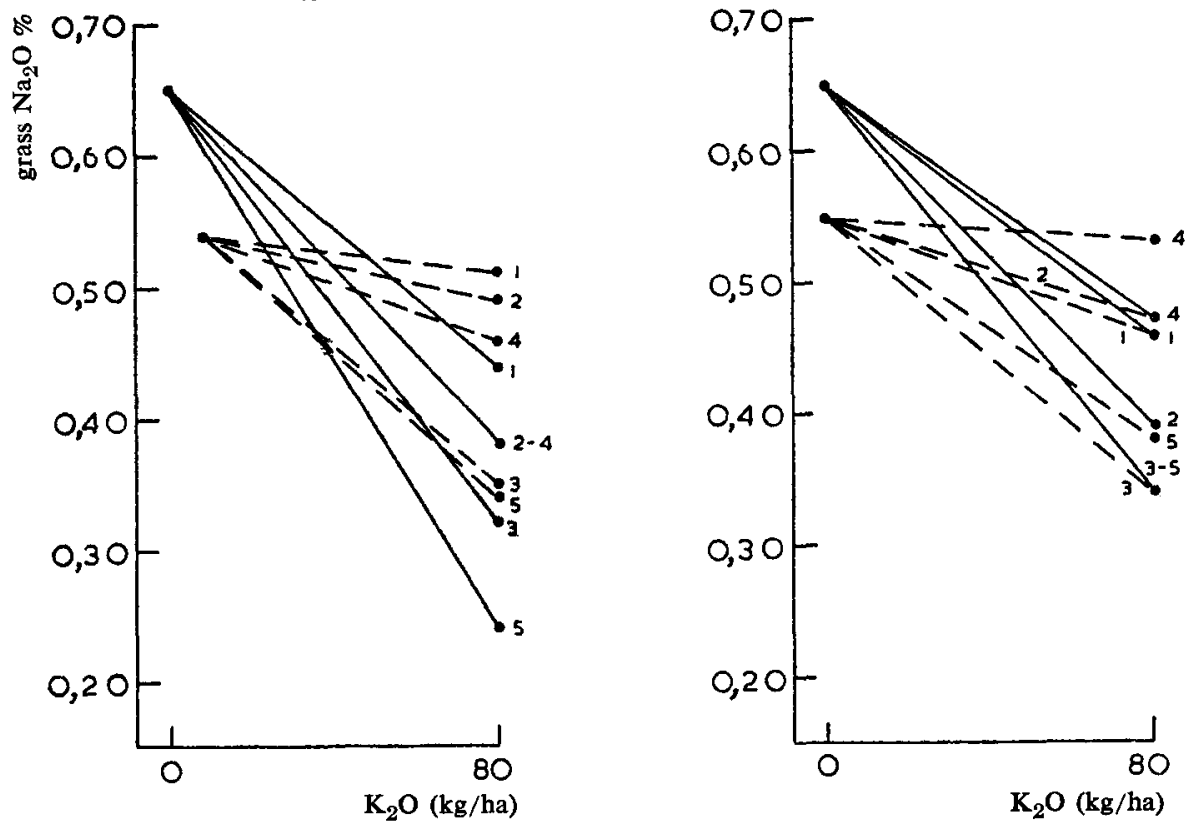

$120 \%$ potash salt

$240 \%$ ",

5 sulphate of potash magnesia

$360 \%$ " "

- $40 \mathrm{~kg} \mathrm{~N} / \mathrm{ha}$

4 kainite 
The results of another trial field also lend support to our conclusion that the influence of sodium-containing potash fertilisers depends on the above-mentioned ratio in the soil. The Potash Company laid down a trial field on clay soil to study the influence of the type of potash fertiliser in combination with a dressing of calcium nitrate or Chilean nitrate. The potash dressing was only given in spring, a nitrogen dressing following each cut (TABLE 3). The sodium content of the grass is low in the treatment without potash and with a dressing of calcium nitrate. It may be assumed that the ratio $\frac{25 \mathrm{~K} \text {-number }}{\mathrm{Na}_{2} \mathrm{O}+14}$ is high. In the first cut the supply of $120 \mathrm{~kg} \mathrm{~K} 2 \mathrm{O} / \mathrm{ha}(20 \%$ potash salt) greatly increases the sodium content but, when supplied in the form of $40 \%$ and $60 \%$ potash salt, the increase is too small. With Chilean nitrate, however, the influence of potash fertilisers is negligible. The explanation may be that the use of Chilean nitrate, as expected, increased the sodium status of the soil and decreased the ratio $25 \mathrm{~K}$-number

$\mathrm{Na} 2 \mathrm{O}+14$. The same observation may be made of the second and third cut. For the later cuts the influence of potash is only slight.

\subsection{Nitrogen fertilisers}

It is known that the potash content of grass increases with an increase in protein content. But in our study we found no influence of the protein content of the grass.

For studying the influence of a fresh nitrogen dressing we had at our disposal the experiments of series 68 and some field experiments of the Netherlands Potash Import Company. The trial fields of series 68 were fertilised with 30 and $60 \mathrm{~kg}$ of nitrogen in the form of ammonium-nitrate limestone. TABLE 4 shows the sodium content of the grass of series 68 with 30 and $60 \mathrm{~kg}$ of $\mathrm{N}$ and a potash supply of 0 and $100 \mathrm{~kg}$ $\mathrm{K}_{2} \mathrm{O} / \mathrm{ha}$ (40\% potash salt). According to this table, on sandy soils at least, nitrogen reduces the sodium content of grass, unless potash has been supplied. With a potash dressing, however, the sodium content is increased by nitrogen fertilisers. The reduction at low ratios may be in agreement with the reduction of sodium by nitrogen dressing when no potash is given simultaneously.

But the results outlined in TABLE 4 are not in agreement with the results of the field experiments of the Netherlands Potash Import Company. In the experiments mentioned in TABLE 2 (FIG. 12, 13 and 14) an increase of nitrogen supply from 40 to $80 \mathrm{~kg}$ of $\mathrm{N} /$ ha caused in the first year (1954) a decrease in the sodium content of all cuts both at high and low potash levels. In the second year (1955), however, the sodium content of the grass was higher with $80 \mathrm{~kg}$ of $\mathrm{N} / \mathrm{ha}$. The results of the third year are in agreement with those of TABLE 4. In 1956 nitrogen reduced the sodium content when potash had not been applied. With a potash dressing of $80 \mathrm{~kg} \mathrm{~K} 2 \mathrm{O} / \mathrm{ha}$, nitrogen was, however, found to increase the sodium content in most cases. Seven other trial fields of the Netherlands Potash Import Company showed that an increase of nitrogen supply from 20 to $40 \mathrm{~kg}$ of $\mathrm{N} /$ ha increased the sodium content of the grass (mean of 1 st and 2nd cut) by 0,08\% (TABLE 5). KEMP (1960) states that a heavy nitrogen dressing increases the sodium content of herbage. After comparing the TABLEs 2,4 and 5 , we are inclined to conclude that the influence of the nitrogen dressing on the sodium content of grass is uncertain, although in most cases it seems to be positive. The effect of Chilean nitrate as a nitrogenous fertiliser is not considered here, but the effect of the sodium is discussed under 3.4 .

3.3. $\quad \mathrm{M}$ agnesium fertilisers

It was already mentioned that the sodium content of Westerwolds ryegrass (Lolium 
TABLE 3. Influence of potash fertilisers on the sodium and potassium contents of grass dressed

\begin{tabular}{|c|c|c|c|c|c|c|c|c|c|c|}
\hline \multirow[t]{3}{*}{ Potash fertiliser } & \multicolumn{4}{|c|}{ 1st cut } & \multicolumn{4}{|c|}{ 2nd cut } & \multirow{2}{*}{\multicolumn{2}{|c|}{$\begin{array}{c}3 \text { rd cut } \\
\text { calcium } \\
\text { nitrate }\end{array}$}} \\
\hline & \multicolumn{2}{|c|}{$\begin{array}{l}\text { calcium } \\
\text { nitrate }\end{array}$} & \multicolumn{2}{|c|}{$\begin{array}{c}\text { Chilean } \\
\text { nitrate }\end{array}$} & \multicolumn{2}{|c|}{$\begin{array}{l}\text { calcium } \\
\text { nitrate }\end{array}$} & \multicolumn{2}{|c|}{$\begin{array}{l}\text { Chilean } \\
\text { nitrate }\end{array}$} & & \\
\hline & $\mathrm{K}_{2} \mathrm{O}$ & $\mathrm{Na}_{2} \mathrm{O}$ & $\mathrm{K}_{2} \mathrm{O}$ & $\mathrm{Na}_{2} \mathrm{O}$ & $\mathrm{K}_{2} \mathrm{O}$ & $\mathrm{Na}_{2} \mathrm{O}$ & $\mathrm{K}_{2} \mathrm{O}$ & $\mathrm{Na}_{2} \mathrm{O}$ & $\mathrm{K}_{2} \mathrm{O}$ & $\mathrm{Na}_{2} \mathrm{O}$ \\
\hline $0 \mathrm{~kg} \mathrm{~K} \mathrm{~K}_{2} \mathrm{O} / \mathrm{ha}$ & 2,94 & 0,11 & 2,96 & 0,28 & 2,78 & 0,19 & 2,78 & 0,63 & 4,52 & 0,18 \\
\hline Potash salt $(20 \%) 1$ & 3,23 & 0,51 & 2,93 & 0,36 & 3,07 & 0,36 & 3,24 & 0,55 & 4,37 & 0,18 \\
\hline Potash salt $(40 \%) 1$ & 3,06 & 0,15 & 3,32 & 0,27 & 3,37 & 0,18 & 2,65 & 0,70 & 4,46 &, 28 \\
\hline Potash salt $(60 \%) 1$ & 3,31 & 0,13 & 2,93 & 0,36 & 3,23 & 0,13 & 3,00 & 0,69 & 4,80 & 0,16 \\
\hline
\end{tabular}

$1120 \mathrm{~kg} \mathrm{~K}{ }_{2} \mathrm{O} / \mathrm{ha}$.

TABLE 4. Na2 O-content of grass with and without potash dressing and dressings of 30 and 60 $\mathrm{kg}$ of $\mathrm{N} /$ ha ammonium-nitrate limestone at varying $\mathrm{K}$-number/sodium-content ratios of a sandy soil (series 68) in percentages

\begin{tabular}{|c|c|c|c|c|c|c|c|c|c|c|c|}
\hline \multicolumn{6}{|c|}{ Sandy soils } & \multicolumn{6}{|c|}{ Clay soils } \\
\hline \multirow{2}{*}{$\frac{15 \mathrm{~K} \text {-number }}{\mathrm{Na}_{2} \mathrm{O}+6}$} & \multicolumn{2}{|c|}{$0 \mathrm{~K}_{2} \mathrm{O} / \mathrm{ha}$} & \multicolumn{2}{|c|}{$100 \mathrm{~K}_{2} \mathrm{O} / \mathrm{ha}$} & \multirow{2}{*}{$\begin{array}{l}\text { No. of } \\
\text { samples }\end{array}$} & \multirow{2}{*}{$\frac{25 \mathrm{~K} \text {-number }}{\mathrm{Na}_{2} \mathrm{O}+14}$} & \multicolumn{2}{|c|}{$0 \mathrm{~K}_{2} \mathrm{O} / \mathrm{ha}$} & \multicolumn{2}{|c|}{$100 \mathrm{~K}_{2} \mathrm{O} / \mathrm{ha}$} & \multirow{2}{*}{$\begin{array}{l}\text { No. of } \\
\text { samples }\end{array}$} \\
\hline & $30 \mathrm{~N}$ & $60 \mathrm{~N}$ & $30 \mathrm{~N}$ & $60 N$ & & & $30 \mathrm{~N}$ & $60 \mathrm{~N}$ & $30 \mathrm{~N}$ & $60 N$ & \\
\hline$\leqslant 20$ & 0,54 & 0,41 & 0,32 & 0,37 & 2 & $\leqslant 20$ & - & - & - & - & - \\
\hline $21-30$ & 0,17 & 0,17 & 0,161 & 0,20 & 2 & $21-30$ & 0,30 & 0,32 & 0,22 & 0,23 & 4 \\
\hline $31-40$ & 0,13 & 0,11 & 0,15 & 0,13 & 2 & $31-40$ & 0,11 & 0,11 & 0,15 & 0,13 & 1 \\
\hline$>40$ & 0,14 & 0,13 & 0,11 & 0,15 & 2 & $>40$ & - & - & - & - & - \\
\hline
\end{tabular}

1 One sample only.

multiflorum var. westerwoldicum) depends on the ratio of soluble and exchangeable sodium to potassium, calcium and magnesium in the soil according to the formula $\frac{10 \mathrm{Na}}{0,1 \mathrm{Ca}+0,2 \mathrm{Mg}+2 \mathrm{~K}}$ (in m.eq.) (van Itallie, 1938). Van der PaAuw (personal communication) also found a decrease in the sodium content of beets with an increasing magnesium content of the soil, which was also accompanied by an increase in potassium content. We examined the influence of magnesium dressing on the sodium content of grass, using the series of field trials Exp. 1326 and 71 dressed with and without magnesium, at two levels of potash supply. The results of the series Exp. 1326 are given in TABLE 6, and those of Exp. 71 in TABLE 7.

TABLE 6 shows that a magnesium dressing of $60 \mathrm{~kg} \mathrm{MgO} / \mathrm{ha}$ hardly influences the sodium content of grass.

The experimental series 71 (TABLE 7) shows, however, that at low ratios of K-number to sodium content of the soil, a dressing with magnesium (100 $\mathrm{kg} \mathrm{MgO} / \mathrm{ha})$ decreases the sodium content of the grass. But this decrease is less pronounced when potash is applied simultaneously. The influence of magnesium is only slight at higher ratios of K-number to sodium content of the soil.

\subsection{Sodium fertilisers}

Apart from sodium-containing potash fertilisers we have at our disposal Chilean nitrate and sodium chloride. Within the framework of series 68 trial fields were laid down with Chilean nitrate at two nitrogen levels (30 and $60 \mathrm{~kg}$ of $\mathrm{N}$ ). 
with calcium nitrate and Chilean nitrate (\%)

\begin{tabular}{|c|c|c|c|c|c|c|c|c|c|c|c|c|c|}
\hline \multirow{2}{*}{\multicolumn{2}{|c|}{$\begin{array}{l}\text { 3rd cut } \\
\text { Chilean } \\
\text { nitrate }\end{array}$}} & \multicolumn{4}{|c|}{ 4th cut } & \multicolumn{4}{|c|}{ 5th cut } & \multicolumn{4}{|c|}{ Mean } \\
\hline & & \multicolumn{2}{|c|}{$\begin{array}{l}\text { calcium } \\
\text { nitrate }\end{array}$} & \multicolumn{2}{|c|}{$\begin{array}{l}\text { Chilean } \\
\text { nitrate }\end{array}$} & \multicolumn{2}{|c|}{$\begin{array}{l}\text { calcium } \\
\text { nitrate }\end{array}$} & \multicolumn{2}{|c|}{$\begin{array}{c}\text { Chilean } \\
\text { nitrate }\end{array}$} & \multicolumn{2}{|c|}{$\begin{array}{l}\text { calcium } \\
\text { nitrate }\end{array}$} & \multicolumn{2}{|c|}{$\begin{array}{l}\text { Chilean } \\
\text { nitrate }\end{array}$} \\
\hline $\mathrm{K}_{2} \mathrm{O}$ & $\mathrm{Na}_{2} \mathrm{O}$ & $\overline{\mathrm{K}}_{2} \mathrm{O}$ & $\mathrm{Na}_{2} \mathrm{O}$ & $\mathrm{K}_{2} \mathrm{O}$ & $\mathrm{Na}_{2} \mathrm{O}$ & $\mathrm{K}_{2} \mathrm{O}$ & $\mathrm{Na}_{2} \mathrm{O}$ & $\mathrm{K}_{2} \mathrm{O}$ & $\mathrm{Na}_{2} \mathrm{O}$ & $\mathrm{K}_{2} \mathrm{O}$ & $\mathrm{Na}_{2} \mathrm{O}$ & $\mathrm{K}_{2} \mathrm{O}$ & $\mathrm{Na}_{2} \mathrm{O}$ \\
\hline 4,04 & 0,73 & 4,23 & 0,19 & 3,75 & 0,63 & 3,82 & 0,23 & 3,82 & 0,31 & 3,66 & 0,18 & 3,47 & 0,52 \\
\hline 4,24 & 0,73 & 4,24 & 0,20 & 3,87 & 0,63 & 4,16 & 0,22 & 3,67 & 0,40 & 3,82 & 0,29 & 3,59 & 0,53 \\
\hline 3,65 & 0,66 & 4,11 & 0,31 & 3,98 & 0,57 & 3,84 & 0,26 & 3,66 & 0,40 & 3,77 & 0,24 & 3,21 & 0,52 \\
\hline 3,71 & 0,61 & 3,72 & 0,27 & 3,60 & 0,59 & 3,79 & 0,24 & 3,75 & 0,30 & 3,77 & 0,19 & 3,40 & 0,51 \\
\hline
\end{tabular}

TABLE 8 shows that $200 \mathrm{~kg}$ of Chilean nitrate increases the sodium content of grass to a sufficient level, even at a high ratio $\frac{15 \mathrm{~K} \text {-number }}{\mathrm{Na}_{2} \mathrm{O}+6}$, whereas in the case of a dressing of $400 \mathrm{~kg}$, the sodium content of the grass is high, even when potash is applied.

To trace the after-effect of a Chilean-nitrate dressing we had at our disposal the trial fields laid down by the Chilean Nitrate Agricultural Service at Wageningen. In these trial fields the sodium content of grass was studied when ammonium-nitrate limestone and Chilean nitrate were applied in spring. On some plots the Chilean nitrate dressing was repeated after the first cut (TABLE 9). This table shows that when nitrogen is given in the form of Chilean nitrate in spring, the sodium content increases up to the fourth cut, but at the end of the year it is about the same as in the case of ammonium-nitrate limestone. The sodium content of the first cut in the following year is hardly increased, even when the Chilean nitrate dressing has been repeated after the first cut in the previous year. We may therefore conclude that the residual effect of Chilean nitrate only lasts for one season.

The Chilean Nitrate Agricultural Service laid down four trial fields to study the value of sodium chloride in comparison with Chilean nitrate. The following treatments were included in these experiments :

1. $60 \mathrm{~kg}$ of $\mathrm{N} / \mathrm{ha}$ in the form of Chilean nitrate in spring $(375 \mathrm{~kg}$ of Chilean nitrate containing $97 \mathrm{~kg} \mathrm{Na}$ ),

2. $30 \mathrm{~kg}$ of $\mathrm{N} /$ ha in the form of Chilean nitrate $+30 \mathrm{~kg}$ of $\mathrm{N}$ as ammonium nitrate limestone in spring,

3. $60 \mathrm{~kg}$ of $\mathrm{N} / \mathrm{ha}$ in the form of ammonium nitrate limestone in spring,

4. $60 \mathrm{~kg}$ of $\mathrm{N} / \mathrm{ha}$ in the form of ammonium nitrate limestone $+250 \mathrm{~kg}$ of sodium chloride in spring,

5. $60 \mathrm{~kg}$ of $\mathrm{N} / \mathrm{ha}$ in the form of ammonium nitrate limestone $+125 \mathrm{~kg}$ of sodium chloride in spring.

For the later cuts all treatments were dressed with ammonium-nitrate limestone.

TABLE 10 shows the mean values of the four trial fields. It can be seen that the influence of Chilean nitrate on the sodium content of grass is equal to that of an equivalent amount of sodium chloride. The calcium and magnesium contents of grass are also specified in TABLE 10 . It can be seen that Chilean nitrate reduces the CaOcontent by nearly $0,1 \%$ compared with sodium chloride. VAN ITALLIE (1937) also found on an average a $0,1 \%$ lower $\mathrm{CaO}$-content in the grass with Chilean nitrate than with sodium chloride. This decrease in $\mathrm{CaO}$-content of grass may be favourable in areas 
TABLE 5. Na2O-content of grass dressed with 20 and $40 \mathrm{~kg}$ oi $\mathrm{N} / \mathrm{ha}$ in the form of

\begin{tabular}{|c|c|c|c|c|c|c|c|c|}
\hline & \multicolumn{8}{|c|}{$40 \%$ Potash-salt application and nitrogen dressings } \\
\hline & \multicolumn{4}{|c|}{$0 \mathrm{~kg} \mathrm{~K} \mathrm{~K}_{2} \mathrm{O}$} & \multicolumn{4}{|c|}{$40 \mathrm{~kg} \mathrm{~K} \mathrm{~K}_{2} \mathrm{O}$} \\
\hline & \multicolumn{2}{|c|}{$20 \mathrm{~kg} \mathrm{~N}$} & \multicolumn{2}{|c|}{$40 \mathrm{~kg} \mathrm{~N}$} & \multicolumn{2}{|c|}{$20 \mathrm{~kg} \mathrm{~N}$} & \multicolumn{2}{|c|}{$40 \mathrm{~kg} \mathrm{~N}$} \\
\hline & $\mathrm{K}_{2} \mathrm{O}$ & $\mathrm{Na}_{2} \mathrm{O}$ & $\mathbf{K}_{2} \mathrm{O}$ & $\mathrm{Na}_{2} \mathrm{O}$ & $\mathrm{K}_{2} \mathrm{O}$ & $\mathrm{Na}_{2} \mathrm{O}$ & $\mathrm{K}_{2} \mathrm{O}$ & $\mathrm{Na}_{2} \mathrm{O}$ \\
\hline Oldeboorn; clay, peaty subsoil & 1,31 & 0,89 & 1,48 & 0,89 & 1,71 & 0,66 & 1,64 & 0,70 \\
\hline Oosterwolde; peat, sandy subsoil & 1,99 & 0,24 & 1,60 & 0,35 & 2,17 & 0,24 & 2,10 & 0,30 \\
\hline Emmen; peat, sandy subsoil ) & 2,04 & 0,20 & 2,24 & 0,28 & 2,67 & 0,24 & 2,87 & 0,27 \\
\hline Emmen; (kainite) ........ & & & & & 1,96 & 0,22 & 2,45 & 0,31 \\
\hline Emmen; peat, sandy subsoil & 2,82 & 0,36 & 2,22 & 0,35 & 2,19 & 0,35 & 2,55 & 0,28 \\
\hline Schoonebeek; clayish peat .. & 2,14 & 0,27 & 2,42 & 0,32 & 2,61 & 0,22 & 2,55 & 0,26 \\
\hline Uitwellingerga; clay, peaty subsoil & 1,83 & 0,46 & 2,06 & 0,55 & 2,35 & 0,36 & 2,36 & 0,40 \\
\hline Oosterhesselen; sandy soil . . & 2,17 & 0,28 & 2,07 & 0,40 & 2,24 & 0,27 & 2,32 & 0,31 \\
\hline Oosterhesselen; (kainite) . . & & & & & 2,34 & 0,27 & 2,39 & 0,44 \\
\hline \multicolumn{9}{|l|}{ Second cut } \\
\hline Oldeboorn; clay, peaty subsoil & 1,31 & 0,70 & 1,19 & 0,67 & 1,98 & 0,43 & 1,92 & 0,61 \\
\hline Oosterwolde; peat, sandy subsoil & 2,05 & 0,24 & 2,04 & 0,35 & 2,64 & 0,26 & 2,66 & 0,31 \\
\hline Emmen; peat, sandy subsoil & 2,30 & 0,23 & 2,13 & 0,36 & 2,36 & 0,22 & 2,32 & 0,32 \\
\hline Emmen; (kainite) ......... & & & & & 2,89 & 0,27 & 2,59 & 0,39 \\
\hline Emmen; peat, sandy subsoil & 2,45 & 0,47 & 2,20 & 0,55 & 2,76 & 0,42 & 3,02 & 0,51 \\
\hline Schoonebeek; clayish peat & 2,47 & 0,31 & 2,94 & 0,34 & 2,83 & 0,23 & 3,13 & 0,30 \\
\hline Uitwellingerga; clay, peaty subsoil & 2,26 & 0,39 & 2,34 & 0,46 & 2,40 & 0,30 & 2,46 & 0,43 \\
\hline Oosterhesselen; sandy soil . . & 2,40 & 0,31 & 2,29 & 0,55 & 2,75 & 0,35 & 3,05 & 0,39 \\
\hline Oosterhesselen; (kainite) ... & & & & & 2,92 & 0,34 & 2,89 & 0,53 \\
\hline
\end{tabular}

All dressings were repeated for each cut.

where the grass has a high $\mathrm{Ca} / \mathrm{P}$-ratio, but it may be unfavourable with grass having a low $\mathrm{Ca} / \mathrm{P}$-ratio.

The magnesium content of grass is slightly reduced both by Chilean nitrate and sodium chloride. The reduction is the same in both cases.

The question may arise as to how far the ratios $\frac{15 \mathrm{~K} \text {-number }}{\mathrm{Na} \mathrm{O}_{2}+6}$ and $\frac{25 \mathrm{~K} \text {-number }}{\mathrm{Na} \mathrm{O}_{2} \mathrm{O}+14}$ are also indicative when potash and sodium is applied, as these ratios change under the influence of potash and sodium fertilisers. To study this point use can be made of experiments of series 68 . In these the K-number and the sodium content of the soil before dressing are known. Some of the plots were fertilised with $100 \mathrm{~kg}$ of $\mathrm{K}_{2} \mathrm{O}$ per ha in the form of $40 \%$ potash salt and with 200 and $400 \mathrm{~kg}$ Chilean nitrate. The $\mathrm{K}$-number of the dressed plots can be calculated by means of the K-number unit ${ }^{1}$. The potash dressing given in the form of $40 \%$ potash salt increased both the K-number and the sodium content of the soil. The sodium content of the plots to which potash was applied was therefore calculated by means of the volume weight and the amount of sodium added (it was assumed that $40 \%$ potash salt contains $18 \%$, and Chilean nitrate $33,7 \% \mathrm{Na}_{2} \mathrm{O}$ ). FIG. 15 and 16 show that the treatments with and without potash and sodium are equally scattered around the curve. It is still necessary to know the increase in the sodium content of the soil due to the application of sodium. The

1 This is the amount of $\mathrm{K}_{2} \mathrm{O}$ needed to increase the $\mathrm{K}$-number of the soil by one unit. 
ammonium-nitrate limestone at varying potash levels (40\% potash salt) in percentages

\begin{tabular}{|c|c|c|c|c|c|c|c|c|c|c|c|}
\hline \multicolumn{4}{|c|}{$60 \mathrm{~kg} \mathrm{~K} \mathrm{~K}_{2} \mathrm{O}$} & \multicolumn{4}{|c|}{$80 \mathrm{~kg} \mathrm{~K}_{2} \mathrm{O}$} & \multicolumn{4}{|c|}{ Mean } \\
\hline \multicolumn{2}{|c|}{$20 \mathrm{~kg} \mathrm{~N}$} & \multicolumn{2}{|c|}{$40 \mathrm{~kg} \mathrm{~N}$} & \multicolumn{2}{|c|}{$20 \mathrm{~kg} \mathrm{~N}$} & \multicolumn{2}{|c|}{$40 \mathrm{~kg} \mathrm{~N}$} & \multicolumn{2}{|c|}{$20 \mathrm{~kg} \mathrm{~N}$} & \multicolumn{2}{|c|}{$40 \mathrm{~kg} \mathrm{~N}$} \\
\hline $\mathrm{K}_{2} \mathrm{O}$ & $\mathrm{Na}_{2} \mathrm{O}$ & $\mathrm{K}_{2} \mathrm{O}$ & $\mathrm{Na}_{2} \mathrm{O}$ & $\mathrm{K}_{2} \mathrm{O}$ & $\mathrm{Na}_{2} \mathrm{O}$ & $\mathrm{K}_{2} \mathrm{O}$ & $\mathrm{Na}_{2} \mathrm{O}$ & $\mathrm{K}_{2} \mathrm{O}$ & $\mathrm{Na}_{2} \mathrm{O}$ & $\mathrm{K}_{2} \mathrm{O}$ & $\mathrm{Na}_{2} \mathrm{O}$ \\
\hline 1,94 & 0,66 & 1,90 & 0,63 & 2,06 & 0,59 & 1,90 & 0,65 & 1,76 & 0,70 & 1,73 & 0,72 \\
\hline 2,28 & 0,24 & 2,26 & 0,27 & 2,35 & 0,24 & 2,36 & 0,30 & 2,20 & 0,24 & 2,08 & 0,31 \\
\hline \multirow[t]{2}{*}{2,48} & 0,27 & 3,16 & 0,28 & 2,34 & 0,16 & 2,82 & 0,27 & 2,38 & 0,22 & 2,77 & 0,28 \\
\hline & & & & 2,35 & 0,23 & 2,82 & 0,31 & 2,16 & 0,23 & 2,64 & 0,31 \\
\hline 2,30 & 0,36 & 2,32 & 0,30 & 2,52 & 0,40 & 2,19 & 0,34 & 2,46 & 0,37 & 2,32 & 0,32 \\
\hline 2,72 & 0,19 & 2,49 & 0,27 & 2,78 & 0,18 & 2,67 & 0,23 & 2,56 & 0,22 & 2,53 & 0,27 \\
\hline 2,43 & 0,35 & 2,51 & 0,38 & 2,31 & 0,31 & 2,43 & 0,35 & 2,23 & 0,37 & 2,34 & 0,42 \\
\hline \multirow[t]{2}{*}{2,72} & 0,27 & 2,65 & 0,31 & 2,86 & 0,26 & 2,42 & 0,27 & 2,50 & 0,27 & 2,37 & 0,32 \\
\hline & & & & 2,63 & 0,30 & 2,47 & 0,38 & 2,49 & 0,29 & 2,43 & 0,41 \\
\hline 2,22 & 0,49 & 2,26 & 0,51 & 2,05 & 0,42 & 2,84 & 0,46 & 1,89 & 0,51 & 2,05 & 0,56 \\
\hline 2,92 & 0,23 & 2,84 & 0,24 & 3,14 & 0,22 & 3,00 & 0,28 & 2,69 & 0,24 & 2,64 & 0,30 \\
\hline 2,65 & 0,22 & 2,84 & 0,39 & 3,06 & 0,19 & 2,94 & 0,34 & 2,59 & 0,22 & 2,56 & 0,35 \\
\hline \multirow[t]{2}{*}{2,82} & 0,36 & 2,82 & 0,39 & 2,90 & 0,32 & 2,96 & 0,36 & 2,90 & 0,30 & 2,78 & 0,38 \\
\hline & & & & 3,07 & 0,38 & 3,40 & 0,40 & 2,78 & 0,41 & 2,86 & 0,46 \\
\hline 3,13 & 0,22 & 3,37 & 0,30 & 3,10 & 0,20 & 3,29 & 0,26 & 2,88 & 0,24 & 3,18 & 0,30 \\
\hline 2,73 & 0,26 & 2,81 & 0,32 & 2,73 & 0,27 & 2,46 & 0,34 & 2,53 & 0,31 & 2,52 & 0,39 \\
\hline \multirow{2}{*}{3,26} & 0,32 & 3,10 & 0,36 & 3,29 & 0,32 & 3,20 & 0,35 & 2,93 & 0,33 & 2,91 & 0,41 \\
\hline & & & & 3,43 & 0,38 & 3,08 & 0,47 & 3,18 & 0,36 & 2,99 & 0,50 \\
\hline
\end{tabular}

calculated sodium content may be too high, giving too low a ratio. This is less important for the K-numbers, since owing to the potash applications recommended in the Netherlands the K-number usually rises to a level at which the influence of Knumber on sodium content is nearly constant $(\geqslant 30)$. This is clear when FIG. 16 is superimposed on FIG. 10. It can be seen that the curve in FIG. 16 has shifted to the left compared with that in FIG. 10. This is caused by the fact that the calculated value for the sodium content of the soil is too high, thus reducing the ratio to below its actual value. The same is true of sandy soils (cf. FIG. 15 with 9), though to a lesser extent.

\section{Influence of the botanical composition of grass}

As mentioned in the literature cited, several investigators have found differences between the sodium content of grasses, clovers and herbs. The question arises as to whether our results can provide additional support when examined on the basis of the sward components. The botanical composition of the pasture in the Soil-PlantAnimal investigation at Borculo is known and the grasses, clovers and herbs have been sampled separately. But the different species of the three components have not been separated.

In FIG. 17, 18 and 19 the sodium content of grasses, clovers and herbs respectively, 
CH. H. HENKENS

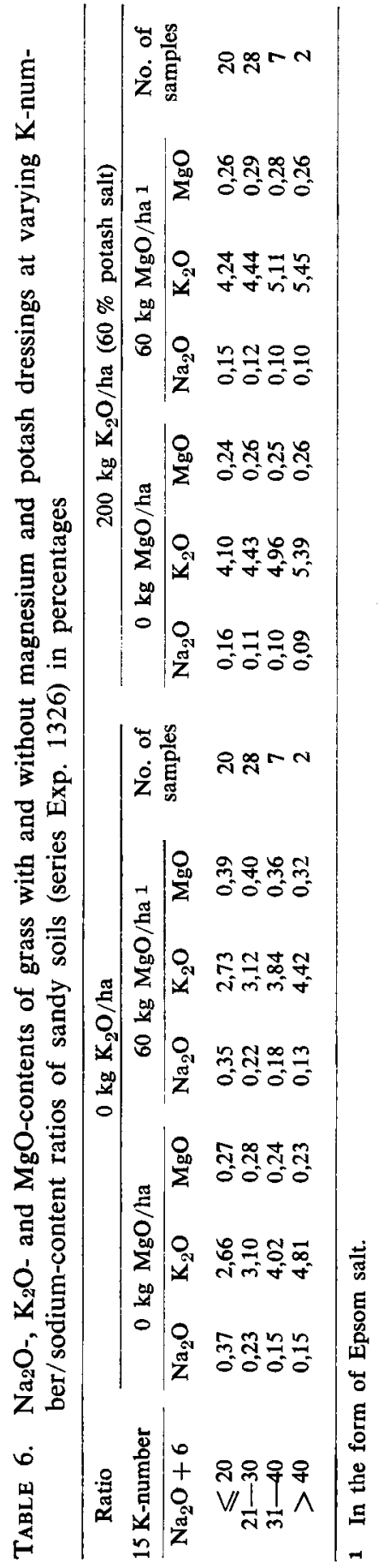

40

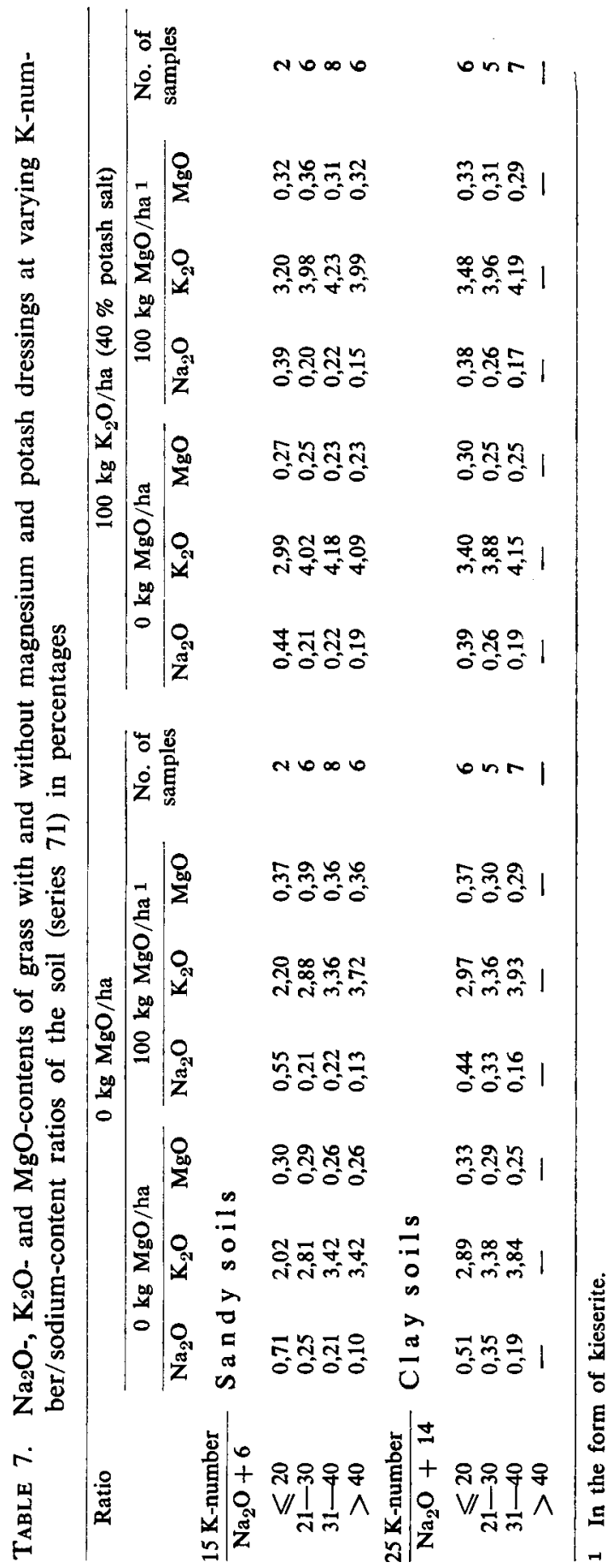

Neth. J. agric. Sci., Vol. 13 (1965) No. 1 (February) 

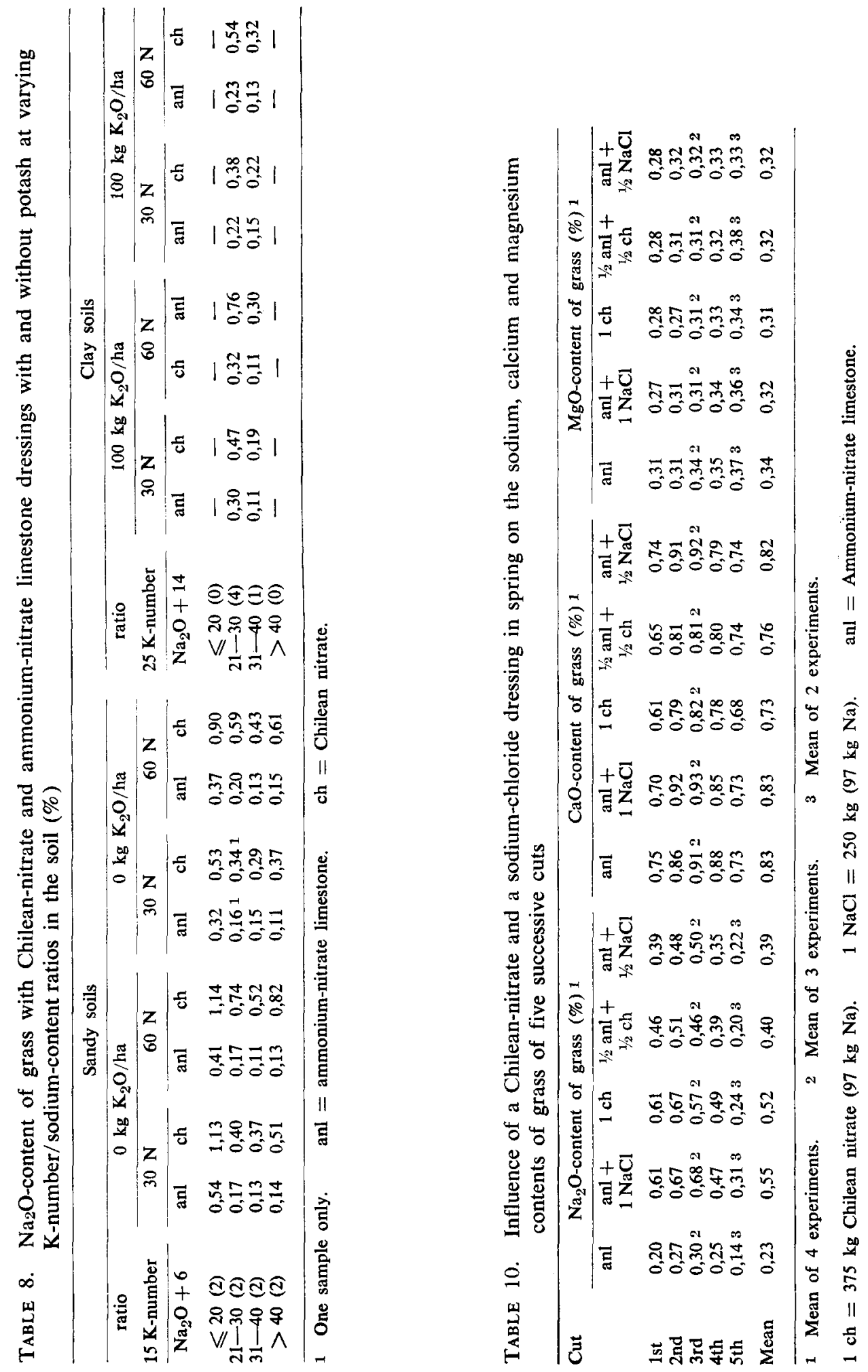


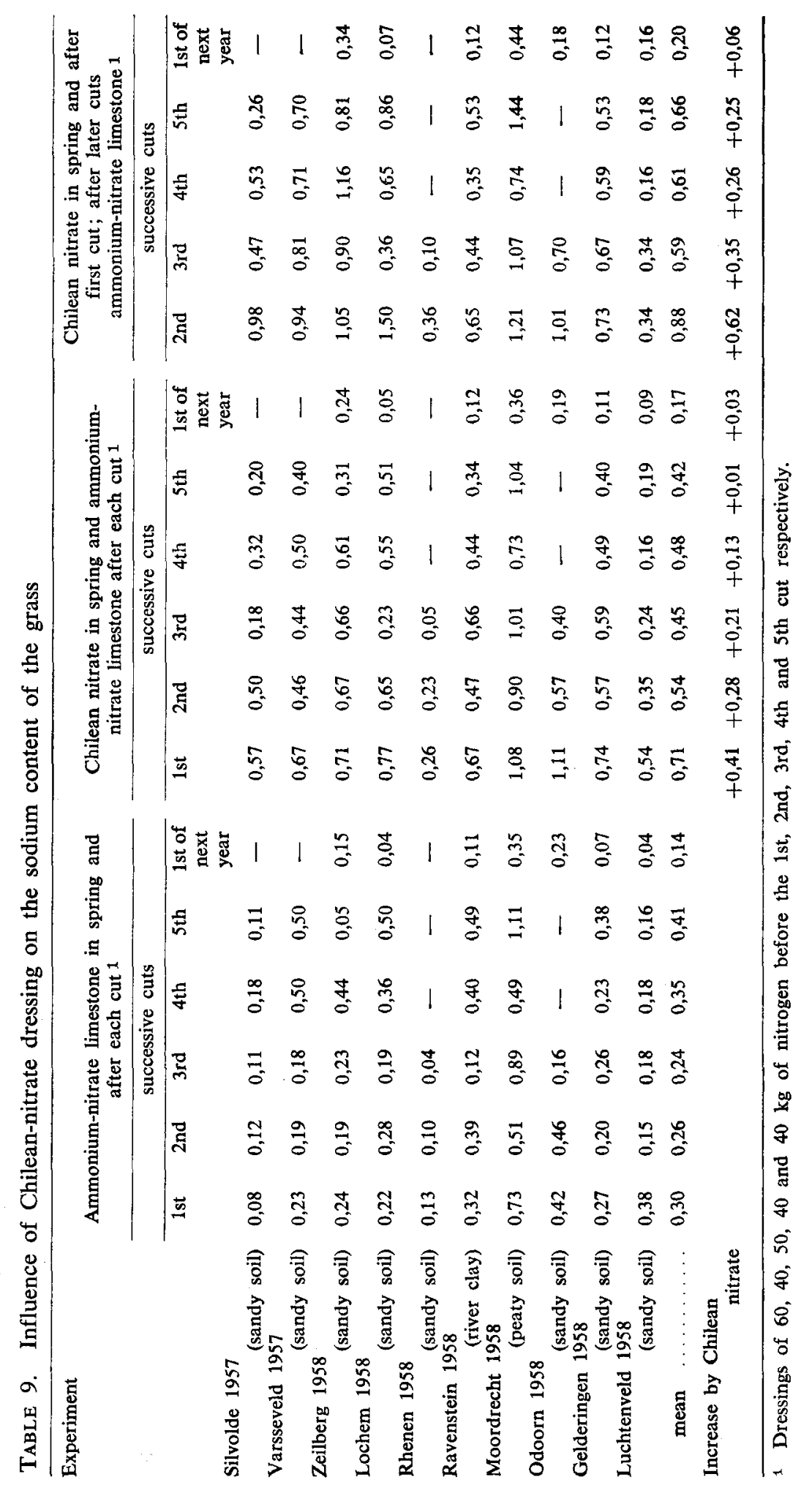




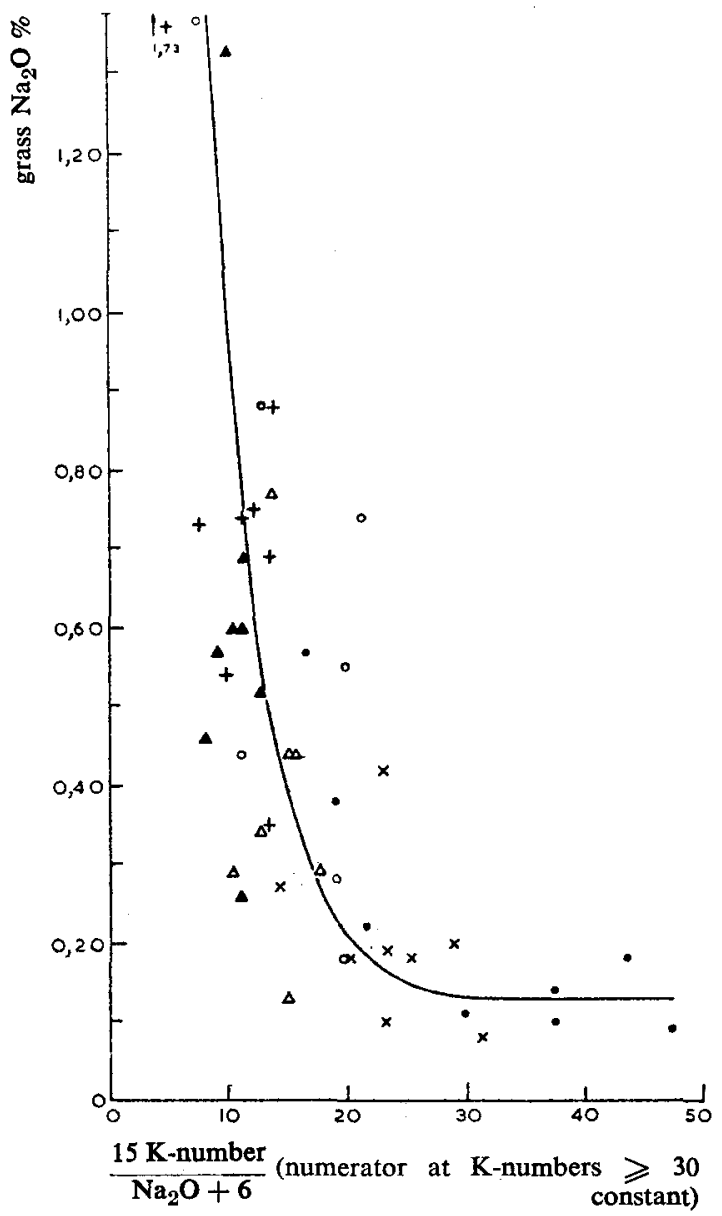

FIG. 15

Relation between the $\frac{15 \mathrm{~K} \text {-number }}{\mathrm{Na}_{2} \mathrm{O}+6^{-}}$ ratio in the soil (numerator at $\mathrm{K}$ numbers $>30$ is the same as at $\mathrm{K}$-number 30 ) and the sodium content of grass on sandy soils (Knumber and sodium content of the soil of the dressed plots calculated)

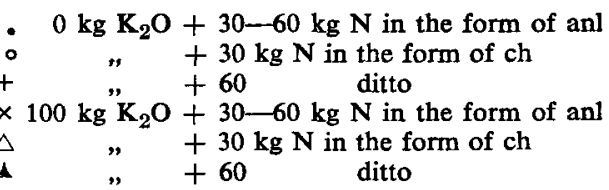

is plotted against the ratio $\frac{15 \mathrm{~K} \text {-number }}{\mathrm{Na} 2 \mathrm{O}+6}$ (numerator at $\mathrm{K}$-number $>30$ the same as at K-number 30). The sodium content of the pasture is calculated from the botanical composition and the sodium content of each component and plotted against the ratio (FIG. 20). The sodium content of the three components separately as well as that of the mixture is related to the ratio $\frac{15 \mathrm{~K} \text {-number }}{\mathrm{Na} 2 \mathrm{O}+6}$ (FIG. 17-20). The deviations of the dots from the curve are, however, greater for clovers and herbs than for grasses. It 


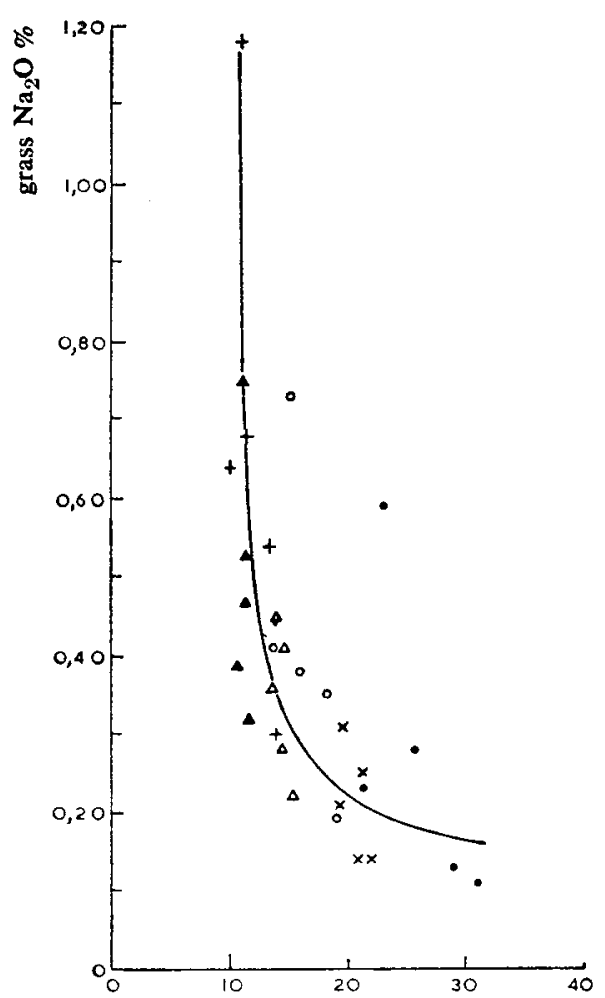

$25 \mathrm{~K}$-number
$\sqrt[\mathrm{Na}_{2} \mathrm{O}+14]{ }$ (numerator at $\mathrm{K}$-numbers
$\geqslant 30$ constant)
FIG. 16

Relation between the $\frac{25 \mathrm{~K} \text {-number }}{\mathrm{Na}_{2} \mathrm{O}+14}$ ratio in the soil (numerator at $\mathrm{K}$-numbers $>30$ is the same as at $\mathrm{K}$-number 30 ) and the sodium content of grass on clay soils (K-number and sodium content of the soil of the dressed plots calculated)

- $0 \mathrm{~kg} \mathrm{~K} \mathrm{~K}_{2} \mathrm{O}+30-60 \mathrm{~kg} \mathrm{~N}$ in the form of anl - $\quad+30 \mathrm{~kg} \mathrm{~N}$ in the form of ch

$+\quad+60$ ditto

$\times 100 \mathrm{~kg} \mathrm{~K}{ }_{2} \mathrm{O}+30-60 \mathrm{~kg} \mathrm{~N}$ in the form of anl $\triangle \quad " \quad+30 \mathrm{~kg} \mathrm{~N}$ in the form of $\mathrm{ch}$

is possible that, especially with herbs, the variation is increased by the presence of different species.

In agreement with the published evidence, herbs appear to have the highest sodium content and grasses the lowest. The differences are greatest at low $\frac{15 \mathrm{~K} \text {-number }}{\mathrm{Na} \mathrm{a}_{2} \mathrm{O}+6}$ ratios and decrease with increasing ratios.

\section{ACKNOWLEDGEMENTS}

The author is much indebted to the Institute for Animal Nutrition, "De Schothorst", the Chilean Nitrate Agricultural Service and the Netherlands Potash Import Company for kindly making available to him their experimental results. 


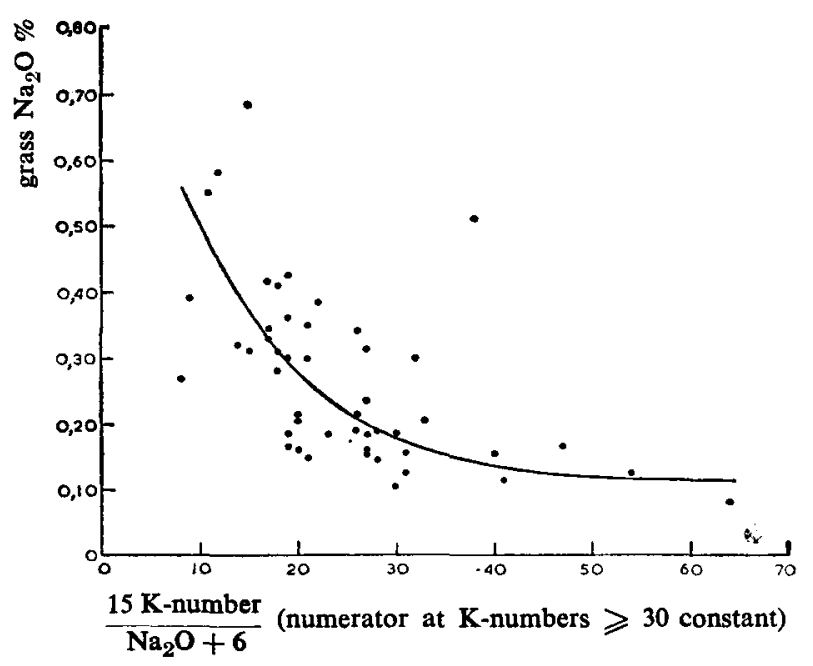

FIG. 17

Relation between the $15 \mathrm{~K}$-number

$\overline{\mathrm{Na}} \mathrm{O}+6$ ratio in the soil (numerator at $\mathrm{K}$-numbers $>\mathbf{3 0}$ is the same as at $\mathrm{K}$-number 30 ) and the sodium content of grass on sandy soils

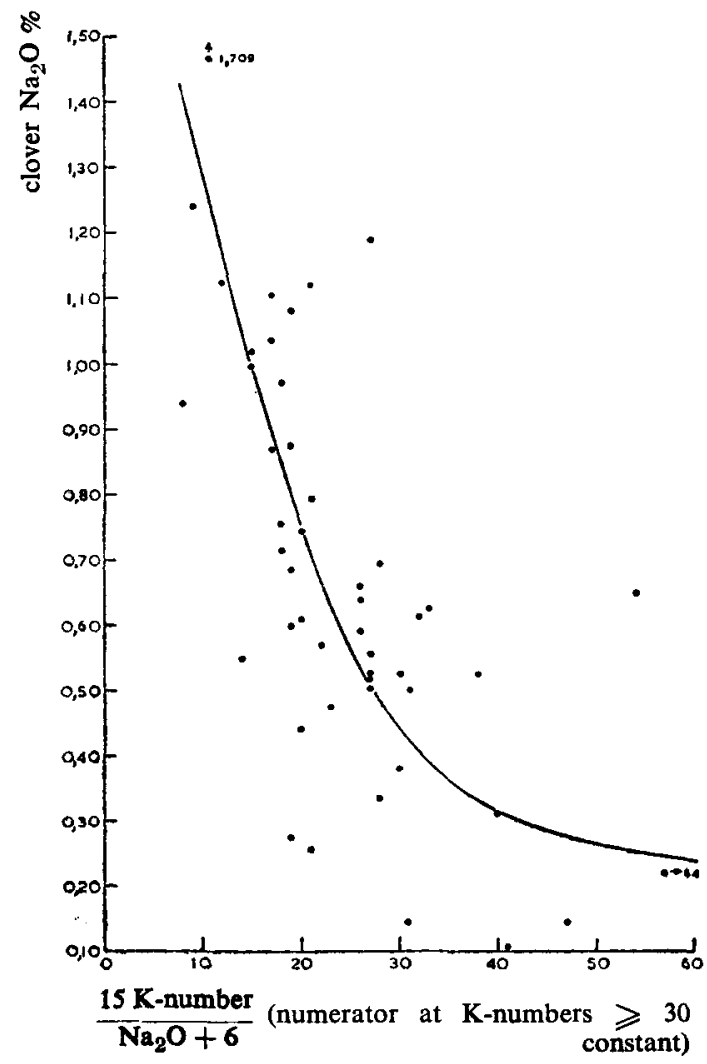

FIG. 18

Relation between the $\frac{15 \mathrm{~K} \text {-number }}{\mathrm{Na} 2 \mathrm{O}+6}$ ratio in the soil (numerator at $\mathrm{K}$-numbers $>30$ is the same as at K-number 30 ) and the sodium content of clover on sandy soils

Neth. J. agric. Sci., Vol. 13 (1965) No. 1 (February) 

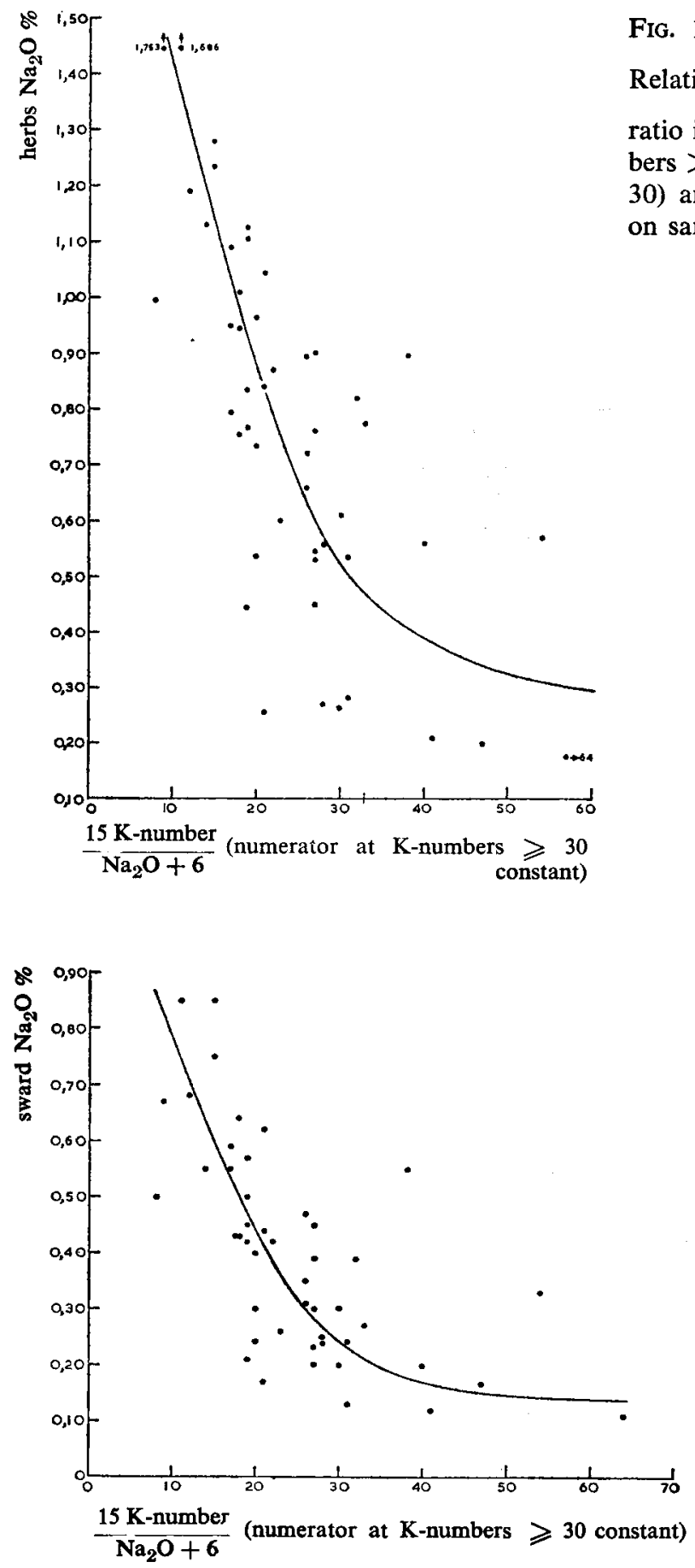

FIG. 19

Relation between the $\frac{15 \mathrm{~K} \text {-number }}{\mathrm{Na} \mathrm{O}_{2} \mathrm{O}+6}$ ratio in the soil (numerator at $\mathrm{K}$-numbers $>30$ is the same as at K-number 30) and the sodium content of herbs on sandy soils
FIG. 20

Relation between the $15 \mathrm{~K}$-number

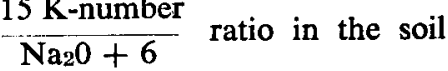
(numerator at K-numbers $>30$ is the same as at $\mathrm{K}$-number 30 ) and the sodium content of the sward on sandy soils 
BRUGGINK, E. G. J.

GarandeauX, J.

HeimanN, H., und R. RATNER

HeNKens, Ch. H., en

B. VAN LUIT

ITALLIE, TH. B. VAN

KEMP, A.

KLEY, F. K. VAN DER

LEHR, J. J.

OOSTENDORP, D.

PaAuw, F. Van Dek

EN J. RIS

\section{REFERENCES}

1960 Enkele gegevens betreffende de macro- en microëlementen in grassen, klavers en kruiden op dezelfde standplaats. Landbk. Tijdschr. 72, 635-643.

1959 Etude de la composition minérale de quelques souches de graminées. Rep. World Congr. Agric. Res., Rome 1959. 593597.

1962 Der Einfluss des Kaliums auf die Natriumaufnahme unter salinen Bedingungen. Kali-Briefe. 24, 14.

1963 Bepaling van de natriumtoestand van grasland met behulp van grondonderzoek. Versl. Landbk. Onderz. No. 69.13, 52 pp.

1934 Chemische samenstelling van een aantal afzonderlijke grassoorten in verschillende groeistadia. Versl. Landbk. Onderz. No. $40,639-643$.

1937a Natrium- en kaliumopname bij verschillende bietenrassen. Versl. Landbk. Onderz. No. 43, 721-766.

$1937 \mathrm{~b}$ De invloed van verschillende factoren op de chemische samenstelling van gras. Landbk. Tijdschr. 49, 1-15.

1938 Cation equilibria in plants in relation to the soil. Soil Sci. 46, $175-186$.

1960 Hypomagnesaemia in milking cows: The response of serum magnesium to alterations in herbage composition resulting from potash and nitrogen dressings on pasture. Neth. J. agric. Sci. 8, 281-304.

1957 Betekenis van de tweezaadlobbige graslandplanten voor de minerale samenstelling van weidegras. Thesis. Wageningen, 1957. $50 \mathrm{pp}$.

1957 The sodium and potassium content of meadow grass under the influence of soil and fertilization. Comm. to the third Fertilizer World Congress, Heidelberg, 1957. 7 pp.

1960 The sodium content of meadow grass in relation to species and fertilization. Eighth Intern. Grassl. Congr., 1960. Paper $3 \mathrm{~A} / 5,101-103$.

1961 De natriumvoorziening van rundvee. Landb.voorl. 18, 609614.

1953 Toetsing van grondonderzoek naar de kalitoestand op Nederlands grasland. Versl. Landbk. Onderz. No. 59.2, 40 pp.

1958 Bemesting van grasland op basis van grondonderzoek. Grasland en graslandproducten (1956) $15-27$. Staatsdrukkerij en Uitgeverij, 's-Gravenhage.

1960 Een nieuw kaligetal voor bouwland op zand- en dalgrond. Landb.voorl. 17, 719-725. 